\title{
Beyond organoids: in vitro vasculogenesis and angiogenesis using cells from mammals and zebrafish
}

Muhammad Ibrahim ${ }^{1,2}$ and Michael K. Richardson ${ }^{1^{*}}$

1. Department of Integrative Zoology, Institute of Biology Leiden, Leiden University, The Netherlands

2. Institute of Biotechnology and Genetic Engineering, The University of Agriculture Peshawar, Pakistan

* Author for correspondence: Institute of Biology Leiden (IBL), Leiden University Sylvius Laboratory, Sylviusweg 72, 2333 BE, Leiden, The Netherlands. Tel. 0031 (0)71 527 5215, Fax: $0031(0) 715274900$

E. mail: $\underline{\text { m.k.richardson@biology.leidenuniv.nl }}$ 


\begin{abstract}
The ability to culture complex organs is currently an important goal in biomedical research. It is possible to grow organoids (3D organ-like structures)in vitro; however, a major limitation of organoids, and other 3D culturesystems, is the lack of a vascular network. Protocols developed for establishing in vitro vascular networks typically use human or rodent cells. A major technical challenge is the culture of functional (perfused) networks. In this rapidly advancing field, some microfluidic devices are now getting close to the goal of an artificially perfused vascular network. Another development is the emergence of the zebrafish as a complementary model to mammals. In this review, we discuss the culture of endothelial cells and vascular networks from mammalian cells, and examine the prospects for using zebrafish cells for this objective. We also look into the future and consider how vascular networks in vitro might be successfully perfused using microfluidic technology.
\end{abstract}

Key words: Angiogenesis; In vitro vascular network; Microfluidics; Organ engineering; Vasculogenesis; Zebrafish 


\section{Introduction}

In multicellular animals, nutrients and oxygen are carried by the cardiovascular system, and diffuse directly into the tissues[1]. Similarly, waste products are removed from the tissues by the same system. This allows the tissues to grow and develop into functional organs[1]. The cells in a living tissue are within 100-200 $\mu \mathrm{m}$ range of a blood capillary[2]. This is important for the survival of the cells as the oxygen and nutrients cannot diffuse through the tissue beyond this range [3].A blood supply (vasculature connected to a pump) has therefore evolved to overcome the constraint on growth imposed by limited diffusion.

One area where blood vessel development is relevant is tissue engineering for regenerative medicine and organ transplantation [4]. Currently, the lack of vascularization of tissues in vitro is a major hurdle in reaching this objective $[5,6]$. This is unfortunate because cultured, vascularized tissues could not only have clinical applications [4], but could also be used as an alternative to whole animal models in research [7]. There are currently great efforts directed towards growing cells and tissues from a patient's own body (autologous transplantation), in order to overcome the potential danger of allogenic (from another individual) graft rejection, and graft-versus-host reactions $[8,9]$.

With current tissue culture techniques, tissues cannot be grown more than 100-200 $\mu \mathrm{m}$ in thickness, primarily because of the limited diffusion of nutrients and oxygen [10]. Tumor cells grown in non-adherent culture can develop into spherical masses (spheroids) up to $3 \mathrm{~mm}$ in diameter, typically with a core of cells that are dead or dying due to diffusion limitation [11]. Similarly, masses of normal (non-malignant) cells grown in vitro are called organoids, and are currently the focus of great interest in biomedical research because they show some organization of tissues resembling in vivo organs[12]. We believe that the development of anin vitro vascular network could improve the culturing of spheroids and organoids (Figure 1) by allowing the tissues to grow and function in a way that is closer to the in vivosituation [13].

Other applications ofvascular network culture could be fundamental studies of vascular development[14];recapitulating disease conditions such as the retinal microvascular abnormalities seen in diabetes[15]or the abnormal angiogenesis in tumor development[16]; 
testing anti-angiogenic compounds in cancer research [17] or candidate drugs for their safe clinical application [18]; and studies in vascular regenerative medicine [19] (Figure 1).
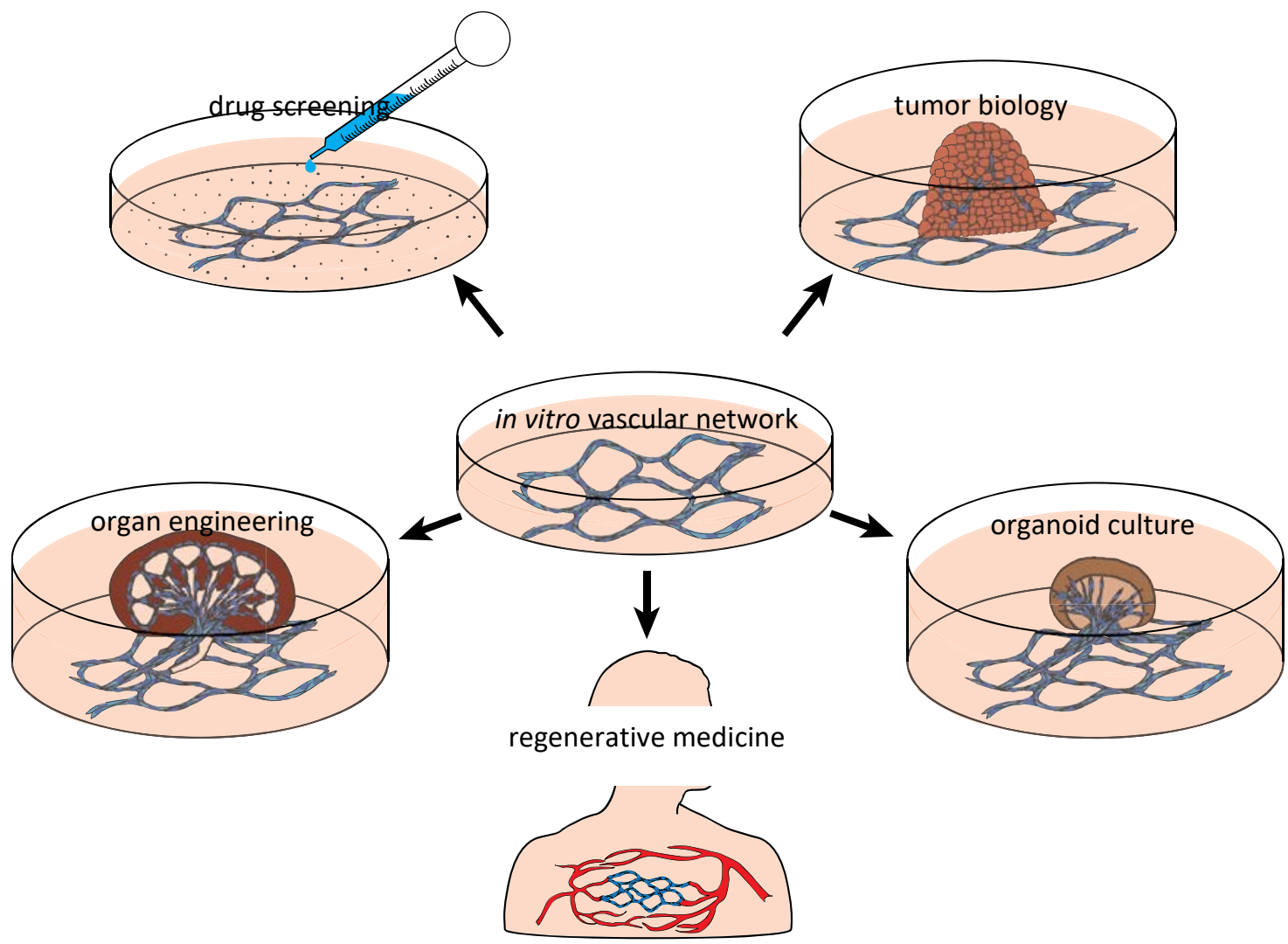

Figure 1: Potential applications of a vascular network culture.

It has long been known from the field of human and animal surgery, including transplant surgery, that tissue can become re-vascularized when grafted to a suitable site[20, 21]. Similarly, developmental studies have shown that embryonic tissues can also readily become re-vascularized, and continue to grow into functional organs, when transplanted to various locations in the embryo[22].Furthermore, embryonic organ primordia can become vascularized if transplanted not only to the embryo itself, but to the vascular network in the extra-embryonic membranes. A good example of this is the chicken embryo chorioallantoic membrane (CAM) system[23, 24]. In that model, organ primordia are placed onto the highly vascular CAM, the blood vessels first having been scratched to open them up. The organ primordia can then form a vascular connection with the CAM vessels, and undergo reasonable growth and morphogenesis. The CAM, however, is highly sensitive to environmental factors [25], therefore the development of the tissue graft is not perfect, possibly because it is not submerged in a supporting volume of fluid, but rather is exposed to 
the air. In a sense, therefore, the CAM and other developmental systems show that the growth of organs on vascular beds is a possibility. What is needed, however, is a vascular bed ex vivo that is perfused by some kind of microfluidic system.

Most of the current research describing vasculogenesis (de novo formation of blood vessels from progenitor cells)and angiogenesis (formation of blood vessels from existing blood vessels) uses mammalian models, mainly mice. However, these models are fairly expensive, time consumingand require ethical and other permissions[26]. Endothelial cell lines such as human umbilical vein endothelial cells (HUVECs) are commonly used for developing in vitro vascular networks[27].Other sources for developing such cultures include embryonic or adult stem cells or tissue explants. The uses and limitations of these techniques are discussed in detail in the following sections.

Zebrafish can be an alternative to mammalian models for studying vascular development[28].The zebrafish produce a large number of fertilized eggs at low cost; the embryos are externally fertilized and therefore readily accessiblefor experiments[29].In some jurisdictions, zebrafish embryos have fewer ethical restrictions. For example, in the European Union, the Directive 2010/63/EU on the protection of experimental animals allows zebrafish embryos to be used until 5 days post fertilization (dpf)without restriction[30].Finally, the zebrafish genome has been sequenced and there is a high level of conservation between zebrafish and human protein coding genes [31]. This similarity supports the use of zebrafish to model various human diseases [32, 33].Because of these advantages, the zebrafish is currently emerging as a model species to study vasculogenesis and angiogenesisin vivo[28]. Transgenic reporter lines are proving very useful in these studies [28].

In this review we give a general overview of vascular development in vivo and the role of various factors in the development of vasculature.Then, we review the current procedures used to culture vascular networks using mammalian endothelial cells and tissue explants. Then,we review the use of zebrafish to study various aspects of vasculogenesis and angiogenesis in vivo. We look forward by summarizing the potential use of zebrafish model for in vitro studies of vascular development.Organoids (organ-like structuresin vitro, lacking a vascular network) which have a limited ability to undergo organogenesis, are discussed in 
the next section. Finally, we summarize studies that use microfluidic technology to develop perfusable vascular networks, and we discuss their potential in the field of tissue engineering.

\section{Development of vasculaturein vivo}

Formation of a vascular system is an essential process in embryonic development. Because multicellular tissues cannot survive without a blood supply, the cardiovascular system is one of the earliest systems formed during embryogenesis[34, 35]. The endothelial precursor cells (angioblasts) differentiate into endothelial cells and undergo the process of vasculogenesis in early embryos to form the primitive blood vessels [36].Studies on zebrafish have shown thatthe angioblasts appear in the lateral mesoderm, migrate to the midline of the embryo and form the first blood vessels [37]. In adult mice and humans, endothelial progenitor cells reside in the bone marrow asmultipotent adult progenitor cells, and contribute to the formation of new blood vessels [38].

Further development of blood vessels takes place by the extension of the preexistingvascular network through the process ofsprouting and non-sprouting angiogenesis [39].During angiogenic sprouting, some endothelial cells within the existing blood vessel are selected as tip cells, and migrate in the direction of angiogenic stimuli[40]. The surrounding extracellular matrix is degraded by specific proteases released during the process [41]. Meanwhile, the stalk cells (endothelial cells following the tip cells) proliferate to extend the blood vessel[40]. Further in development the vascular network also extends through intussusceptive or non-sprouting angiogenesis [42]. The mature blood vessels attain arterial, venous and lymphatic differentiation types having different structures and functions [43]. Endothelial differentiation and blood vessel formation is a complex process which requires a number of growth factors, cell types and extracellular matrix (ECM) components, discussed in the following section. 


\section{Factors controlling vasculogenesis and angiogenesisin vivo}

\subsection{Protein factors influencing vascular development}

The differentiation of endothelial cells and the formation of blood vessels is mainly controlled by several protein factors[44].Important protein factors in this context are summarized inTable 1 . Some of these factors are released by the endothelial cells themselves, other factors are stabilizing signals released by other cell types[44]. The differentiation of angioblasts is induced mainly by fibroblast growth factor 2 (FGF-2) and bone morphogenic protein-4 (BMP-4) [43]. FGF-2inducesthe expression of vascular endothelial growth factor (VEGF) and other important chemokines required to control vascular morphogenesis[45]. The importance of FGF-2 for vascular formation has been shown in studies on quail and zebrafish embryos [46, 47].Similarly, BMP-4 deficiency is associated with severe abnormalities in early mouse embryos, including the lack of a wellorganized vasculature [48].

Among the endothelial growth factors, VEGFs play the predominant role in regulating the formation of blood vessels [49]. The VEGF family consists of several VEGF genes of which VEGF-A, which interacts with endothelial cells through VEGF receptor 2 (VEGFR2 also known as KDR or FLK1), is the main component responsible for the viability and proliferation of endothelial cells [50]. The VEGF mRNA is alternatively spliced resulting in four different isoforms of VEGF $\left(V_{E G F_{121}}, V_{E G F} F_{165}, V_{E G F} F_{189}, V_{E G F}{ }_{206}\right)$, denoted by the number of amino acids in their peptide chain[51]. These isoforms, having different rates of diffusion in the ECM due to differences in their heparin binding ability, generate a gradient, producing chemical signals for the directional migration of newly forming capillaries [52].VEGFs also have important roles in the differentiation, migration and cell-cell adhesion of endothelial cells, as well asstimulating sprouting angiogenesis and the activationof tip cells[53].

Placental growth factor (PIGF), a member of VEGF family expressed in the placenta of early mammalian embryos, has a role in the activation of VEGFR2 and establishing interaction between VEGF-A and VEGFR2 [54]. PIGFhas been demonstrated to increase the angiogenic potential of VEGF in ischemic myocardium in mouse [55]. PIGFexpression is normally low in adult tissues, buthigh in pathological conditions, especially in cancer, where it promotes tumour angiogenesis[56]. 
Table 1. Description and role of different proteins involved in vascular development.

\begin{tabular}{|c|c|c|c|c|}
\hline Protein Type & Name & Origin & Role in vascular development & Ref. \\
\hline \multirow[t]{9}{*}{$\begin{array}{l}\text { Secreted } \\
\text { protein }\end{array}$} & $\begin{array}{l}\text { VEGF-A, B } \\
\text { and } C\end{array}$ & $\begin{array}{l}\text { Endothelial and } \\
\text { parenchymal } \\
\text { cells }\end{array}$ & $\begin{array}{l}\text { VEGF-A: endothelial cellsurvival factor, main } \\
\text { regulator of vascular development; VEGF- } \\
\text { B:coronary vascularization; VEGF-C:lymphatic } \\
\text { system }\end{array}$ & [51] \\
\hline & PIGF & $\begin{array}{l}\text { Mesenchymal } \\
\text { cells }\end{array}$ & $\begin{array}{l}\text { Embryonic vascular development, pathological } \\
\text { angiogenesis }\end{array}$ & [54] \\
\hline & PDGF-B & Endothelial cells & $\begin{array}{l}\text { Vessel maturation;binds to PDGF receptor- } \beta \text { on } \\
\text { pericytes }\end{array}$ & [49] \\
\hline & FGF-2 & $\begin{array}{l}\text { Multiple cell } \\
\text { types }\end{array}$ & $\begin{array}{l}\text { Differentiation of angioblasts; stimulation of } \\
\text { VEGF expression; maintenance of vascular } \\
\text { integrity }\end{array}$ & {$[43,45]$} \\
\hline & Ang-1 & Mural cells & $\begin{array}{l}\text { Maintenance of endothelial cell quiescence; } \\
\text { stabilization of vessel walls }\end{array}$ & {$[44,49]$} \\
\hline & Ang-2 & $\begin{array}{l}\text { Angiogenic tip } \\
\text { cells }\end{array}$ & $\begin{array}{l}\text { Acts as antagonist of Ang-1; promotes } \\
\text { endothelial cell proliferation }\end{array}$ & {$[44,49]$} \\
\hline & TGF- $\beta$ & $\begin{array}{l}\text { Endothelial and } \\
\text { mesenchymal } \\
\text { cells }\end{array}$ & $\begin{array}{l}\text { Embryonic vascular development; induces } \\
\text { vascular smooth muscle cell differentiation }\end{array}$ & {$[57,58]$} \\
\hline & BMP-4 & Mesoderm & $\begin{array}{l}\text { Differentiation of angioblasts; induction of VEGF } \\
\text { expression }\end{array}$ & {$[43,59]$} \\
\hline & Egfl-7 & Endothelial cells & $\begin{array}{l}\text { Facilitates tube formation by coordinating } \\
\text { endothelial cell-cell contact and migration. }\end{array}$ & {$[60]$} \\
\hline \multirow[t]{5}{*}{$\begin{array}{l}\text { Membrane } \\
\text { proteins }\end{array}$} & $\begin{array}{l}\text { VEGFR1, } \\
\text { R2 and R3 }\end{array}$ & $\begin{array}{l}\text { Endothelial and } \\
\text { hematopoietic } \\
\text { cells }\end{array}$ & $\begin{array}{l}\text { VEGFR1 and R2 bind to VEGF-A, B and PIGF. } \\
\text { VEGFR2 is the main mediator of angiogenesis. R3 } \\
\text { binds to VEGF-C }\end{array}$ & [51] \\
\hline & $\begin{array}{l}\text { Ephrin-B2 } \\
\text { and B4 }\end{array}$ & Endothelial cells & Specification of arteries and veins & {$[43,44]$} \\
\hline & $\begin{array}{l}\text { VE- } \\
\text { cadherin }\end{array}$ & Endothelial cells & $\begin{array}{l}\text { Maintenance of endothelial cell-cell contact and } \\
\text { inhibition of endothelial proliferation }\end{array}$ & {$[61]$} \\
\hline & DII-4 & $\begin{array}{l}\text { Endothelial tip } \\
\text { cells }\end{array}$ & $\begin{array}{l}\text { Induces Notch signalling in response to VEGF-A in } \\
\text { sprouting angiogenesis }\end{array}$ & {$[62]$} \\
\hline & $\begin{array}{l}\text { Notch-1 } \\
\text { and } 4\end{array}$ & $\begin{array}{l}\text { Endothelial stalk } \\
\text { cells }\end{array}$ & $\begin{array}{l}\text { Restricts formation of endothelial tip-cell in } \\
\text { response to Dll-4, ensures directional sprouting }\end{array}$ & {$[62]$} \\
\hline
\end{tabular}

Abbreviations: Ang, angiopoietin; BMP, bone morphogenetic protein; DIl, delta like ligand; FGF, fibroblast growth factor; PDGF, platelet-derived growth factor; PIGF, placental growth factor; TGF- $\beta$, transforming growth factor $\beta$; VE-cadherin, vascular endothelial cadherin; VEGF, vascular endothelial growth factor; VEGFR, vascular endothelial growth factor receptor.

Other growth factors involved in the spreading and maturation of blood vessels include angiopoietins (Ang-1 and Ang-2)[63], platelet-derived growth factor-B (PDGF-B) [64] and transforming growth factor $\beta$ (TGF- $\beta$ ) [65], reviewed in Refs. [44, 49]. Epidermal growth factor (EGF)-like domain-7 is also secreted by endothelial cells, which facilitatesthe formation of vascular tubes[60].Many other transcription factors and signalling molecules have been identified to be involved in the differentiation of endothelial cells and the regulation of vascular development reviewed in Ref.[66].In response to low oxygen levels in the tissues, Hypoxia inducible factors (HIFs) regulates the expression of a number of proangiogenic factors including VEGF, PIGF, Ang-1, Ang-2 and PDGF-B[67]. The HIFs are 
considered to be the principle mediators of in vivo vasculogenesis and angiogenesis at all developmental stages[67].

In addition to the secreted protein factors, membrane proteins on the surface of endothelial cells also play an important role in vascular morphogenesis (Table 1). Examples of these membrane proteins include vascular endothelial cadherin (VE-cadherin), which functions to maintain endothelial cell-cell contact during VEGF-induced migration[61];and delta like ligand-4 and Notch-1, which specifythe endothelial tipvs. stalk cells during sprouting angiogenesis[62].

\subsection{Role of other cell types in vascular development}

In addition to the secreted and membrane-bound protein factors discussed above, cell types other than endothelial cells also contribute to the formation of blood vessels. Pericytes and smooth muscle cells promote the proliferation and survival of endothelial cells and provide structural support to the blood vessels $[68,69]$. Pericytes possess a number of receptors specific for the binding of angiogenic growth factors (such as PDGF-B and TGF- $\beta$ ) released by endothelial cells[70]. Similarly, the receptor for Ang-1 (a growth factor released by pericytes and other mural cells) is expressed on endothelial cells. This interaction between pericytes and endothelial cells contributes to angiogenic sprouting, vessel maturation and maintenance[70]. In the blood vessels of the central nervous system, pericytes have been reported to express tight and adherens junction proteins, thus regulating the permeability of blood-brain barrier [71].

Macrophagesare reported to be involved in connecting two blood vessel sprouts in the process called anastomosis [72]. A similar function is performed by microglial cells in the central nervous system, promoting the development of a complex vascular network [73]. Under certain conditions (e.g. hypoxia), the parenchymal cells (neurons, hepatocytes, myocytes etc.) release angiogenic growth factors to initiate sprouting angiogenesis [74].Platelets have been shown to contain isolated granules with stored pro- or antiangiogenic factors[75]. These granules are released selectively upon distinct stimulation pathways, favouring or hinderingangiogenesis [76]. Similarly, adipose stromal cells(a population of adult stem cells residing in fat tissue) release growth factors (such as VEGF, TGF- $\beta$ and FGF) under ischemic conditions, promoting angiogenesis[77]. 


\subsection{Role of extracellular matrix}

Extracellular matrix (ECM)contributes to the formation and diversity of blood vessels in several ways including: (i) maintaining the histological structure and elasticity of the vessels, (ii)regulating the proliferation and differentiation of endothelial cells, and (iii) transporting, modifying or blocking the angiogenic growth factors[78].The ECM is a complex network of macromolecules and its composition and properties are highly variable among different tissues, affecting the tissue-specific differentiation of stem cells [79]. The protein components of ECM interact specifically with the transmembrane protein integrinswhich activate signalling pathways inside the cells, resulting in expression of particular genes that influence cellular differentiation [80].The biophysical properties of ECM (stiffness, elasticity etc.) are also thought to induce cellular pathways (collectively known as mechanotransduction pathways) affecting cell behaviour and fate [81].

Endothelial cells synthesize their own ECM, the major components of which typically include collagen type-IV, nidogens, heparansulfate proteoglycans and laminins [82]. Research on the ECM of blood vessels have shown the presence of different ECM components at different stages of vascular development [83]. In the beginning of the process, the endothelial cells adhere to and migrate on a laminin-rich ECM which is later replaced by a collagen type-I rich ECM to support vascular tube formation [83]. Another layer of ECM in the wall of blood vessels (the medial layer or tunica media) is synthesized by smooth muscle cells and includes fibrillin microfibrils, collagens and elastin as major components [84].Large vessels have an outer adventitial layer of ECM, containing fibronectin, fibrillar collagen and other proteins [84].The ECM of actively growing blood vessels also contains higher levels of fibronectin and its distinct splice isoforms, compared to the ECM of quiescent vessels [85].At sites of injury, platelets secrete fibrinogen which coagulates into a fibrin clot providing a substrate for wound healing [86].

The effect of collagen type-I, fibrin [87], collagen type-IV [88], fibronectin [89] and laminin [90] on vascular development in vitro has also been demonstrated. Matrigel ${ }^{\circledR}$ contains Engelbreth-Holm-Swarm tumor-derived ECM and has been used for various in vitro and in

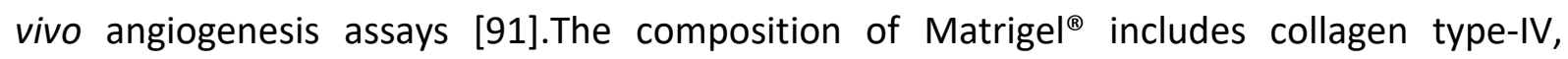
laminin, entactin and heparansulfate proteoglycan as well as growth factors such as FGF, PDGF, EGF and TGF- $\beta$ [91]. In addition to these naturally-derived ECM components, synthetic 
biopolymers (such as polyethylene glycol and poly-D-lysine) have also been proven to enhance vasculogenesis and angiogenesis in vitro $[92,93]$.

\subsection{Haemodynamic factors}

Shear stress generated by blood flow on the luminal surface of endothelial cells is a mechanical factor that induces intracellular biochemical pathways resulting in gene expression changes and the modulation of the structure and function of blood vessels [94]. Heparin binding EGF-like growth factor is one such factor which is expressed in response to reduced blood flow and induces vessel narrowing [95]. Other molecular pathways involved in vascular remodelling are reported to be regulated by changes in shear stress leading to the expression of PIGF [96], Notch-1 [97], and Smad6 (involved in TGB- $\beta$ signalling) proteins [98].

Microfluidic culture of endothelial cells is currently an emerging technology which mimics the physiological shear stress on cultured cells to achieve the goal of culturing functional blood vessels for tissue engineering $[13,99]$. A number of techniques for culturing vascular networks have been described in which endothelial growth factors, ECM components and microfluidics are combined (see following sections for detailed discussion); however, the development of fully functional blood vessels still remains a challenge [99].

\section{Culture of vascular networks using endothelial cells}

Pure endothelial cell populations can develop into vascular network-like structures in culture [27]. However, these networks are not sufficiently robust to be used for tissue engineering; they are mainly used to screen pro- and anti-angiogenic compounds for activity. Pure endothelial cell populations are derived from various sources including embryonic stem cells, induced pluripotent stem cells and adult tissues (Figure 2; [100]). Human macro- and microvascular endothelial cells are commercially available [101-104] and have the ability to form vascular networks in vitro. The most commonly used endothelial cells in this regard are the HUVECs [27, 90, 105-110], derived from the veins of the umbilical cord (Table 2). Other endothelial cell types such as bovine aortic endothelial cells [111] and rat aortic endothelial cells [112] have also been used to culture vascular networks. 


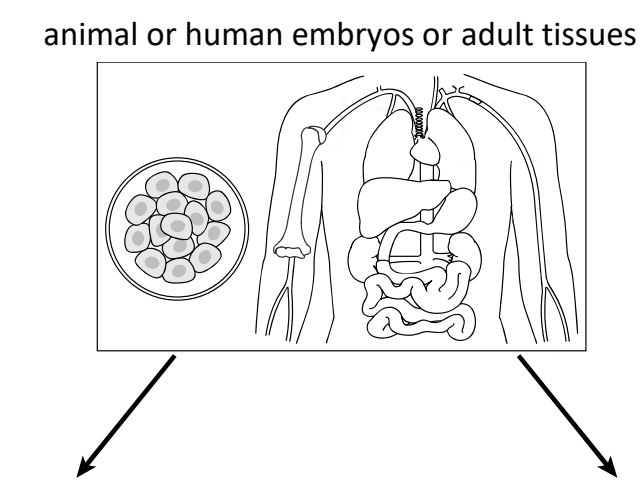

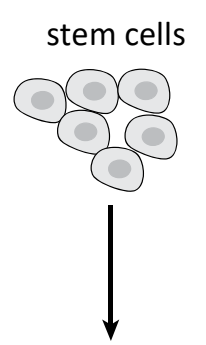

cell differentiation

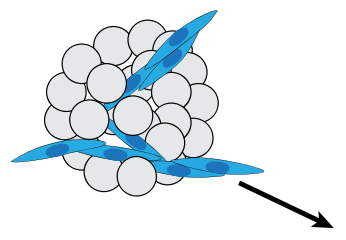

$\downarrow$ pure endothelial cells

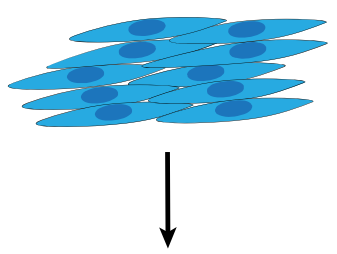

co-culture

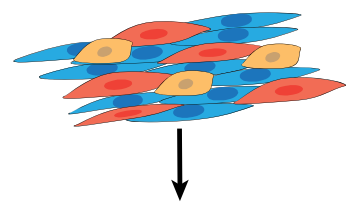

organ explant
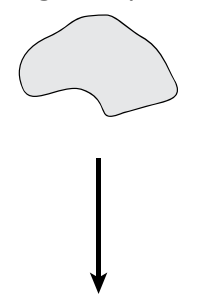

vascular sprouting

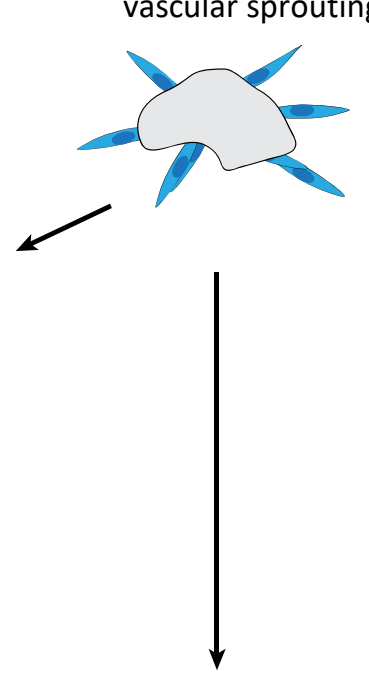

vascular network formation in extracellular matrix

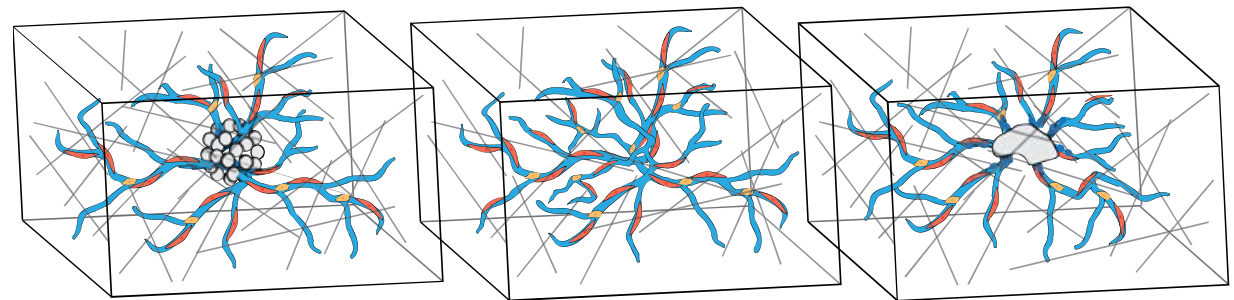

Figure 2. Schematic overview of three possible approaches to establishing cultures of vascular networks. Stem cells, depending on their source, could be embryonic stem cells, mesenchymal stem cells, or induced pluripotent cells. Endothelial cells are in blue; diverse supporting cells are represented schematically by red and yellow.

By contrast, the culture of well-defined vascular networks with a lumen requires the coculture of multiple cell types with endothelial cells [100]. The important supporting cell types,known to induce network formation by endothelial cells, include pericytes[113], 
mesenchymal stem cells [109], fibroblasts [107], hepatocytes [114], smooth muscle cells[115] and adipose-derived stem cells (ASCs) [106]. The importance of fibroblasts in enhancing angiogenesis has been shown in co-culture with HUVECs[107, 116]. Growth factors derived from fibroblast cultures in conditioned medium have also been shown to increase vascular morphogenesis and vessel stability from HUVECs in 3D fibrin gels[108].Furthermore, the ECM components and angiogenic growth factors secreted by fibroblasts have been found to be critical for vascular tube formation from HUVECs[117].

The culture of vascular networks is established in naturally-derived matrices (such as Matrigel ${ }^{\circledR}$ [116], collagen type-I [118] and fibrin [106]); as well as in synthetic matrices ( such as Puramatix ${ }^{\mathrm{TM}}$ [87] and polyethylene glycol hydrogel [119]) both of which types mimic native ECM. These matrices are particularly valuable for promoting successful vascular morphogenesis in vitro [92]. For a vascular network formation, the endothelial cells may be cultured on a 2D surface coated with one or a combination of these gel matrices; or in a 3D gel matrix (Table 2). In one study with HUVECs, increasing the thickness of Matrige ${ }^{\circledR}$ was shown to increase the mean vascular cord length, and to decrease the network density [119].Combinations of different gel components can be used to mimic the complexity of natural ECM. The addition of laminin to collagen type-I scaffoldshas been shown to increase network formation and VEGFR2 expression by HUVECs in culture[90]. Similarly, increased network formation from HUVECs was observed in composite collagen type-l/fibrin matrix compared to pure collagen [110].

Studies in which vascular networks are cultured from endothelial cells have revealed the important role of several cellular and molecular factors. In one study, ASCs were found to enhance vascular network formation from HUVECs in 3D fibrin gels [106]. That study showed that the expression of angiogenesis related genes (VE-cadherin, VEGFR2) and proteins (VEGF, FGF, Ang-1) was higher in ASCs/HUVECs co-culture compared to pure HUVECs culture [106]. ASCs have also been shown to be critical for vascular network formation from blood vascular and lymphatic endothelial cells [120].Studies on human dermal microvascular endothelial cells have revealed the role of VEGF in specialization of the tip endothelial cells and their directional migration to form capillary-like structures [121]. Similarly, inducing the Notch signalling pathway upregulated VEGF-A, VEGF-B and VEGF-R1 expressions, and 
promoted vascular network formation in co-cultured mouse brain microvascular endothelial cells and ASCs in 3D collagen type-I gel [122].

Table 2. Endothelial cell cultures for vascular morphogenesis.

\begin{tabular}{|c|c|c|c|c|c|c|}
\hline $\begin{array}{l}\text { Interacting } \\
\text { Cell types }\end{array}$ & $\begin{array}{l}\text { Culture } \\
\text { strategy }\end{array}$ & $\begin{array}{l}\text { ECM } \\
\text { Substrate }\end{array}$ & $\begin{array}{l}\text { Medium } \\
\text { additives }\end{array}$ & Main outcomes & $\begin{array}{l}\text { Possible } \\
\text { applications }\end{array}$ & Ref. \\
\hline HUVEC & $2 \mathrm{D}$ & BME & EGM-2 & Vascular network formation. & Drug screening & [27] \\
\hline $\begin{array}{l}\text { HUVEC } \\
\text { HBMSC }\end{array}$ & $3 D$ & $\begin{array}{l}\text { Col-1 + } \\
\text { Laminin }\end{array}$ & $\begin{array}{l}\text { EGM, } \\
\text { DMEM }\end{array}$ & $\begin{array}{l}\text { Laminin and HBMSCs } \\
\text { promoted vascular network } \\
\text { formation. }\end{array}$ & $\begin{array}{l}\text { Tissue } \\
\text { engineering }\end{array}$ & [90] \\
\hline HUVEC & $2 \mathrm{D}$ & Matrigel $^{\circledR}$ & RPMI 1640 & $\begin{array}{l}\text { The anti-angiogenic effect of } \\
\text { WIF-1 was reversed by } \\
\text { hypoxic conditions. }\end{array}$ & Cancer research & [105] \\
\hline $\begin{array}{l}\text { HUVEC } \\
\text { ASC }\end{array}$ & $3 D$ & Fibrin & EGM-2 & $\begin{array}{l}\text { Vasculogenesis was more } \\
\text { stable in co-culture with } \\
\text { ASC. }\end{array}$ & $\begin{array}{l}\text { Tissue } \\
\text { engineering }\end{array}$ & [106] \\
\hline $\begin{array}{l}\text { HUVEC } \\
\text { HDF }\end{array}$ & $2 \mathrm{D}$ & & $\begin{array}{l}\text { M199, } \\
\text { ECGS, CS }\end{array}$ & $\begin{array}{l}\text { HDF co-culture and bio- } \\
\text { active silicate stimulated } \\
\text { network formation. }\end{array}$ & $\begin{array}{l}\text { Tissue } \\
\text { engineering }\end{array}$ & [107] \\
\hline $\begin{array}{l}\text { HUVEC } \\
\text { SF }\end{array}$ & $3 D$ & Fibrin & $\begin{array}{l}\text { EGM-2, } \\
\text { VEGF, bFGF, } \\
\text { Ang-1, TGF- } \\
\beta\end{array}$ & $\begin{array}{l}\text { Fibroblast derived-growth } \\
\text { factors enhancedsprouting, } \\
\text { lumen formation and vessel } \\
\text { stability. }\end{array}$ & $\begin{array}{l}\text { Developmental } \\
\text { studies }\end{array}$ & [108] \\
\hline $\begin{array}{l}\text { HUVEC } \\
\text { hES-MC }\end{array}$ & $3 D$ & Col-1 + Fbn & $\begin{array}{l}\text { DMEM/F12, } \\
\text { VEGF, bFGF, } \\
\text { HGF }\end{array}$ & $\begin{array}{l}\text { hES-MC and HGF stabilized } \\
\text { vascular network. }\end{array}$ & $\begin{array}{l}\text { Regenerative } \\
\text { medicine, drug } \\
\text { screening }\end{array}$ & [109] \\
\hline $\begin{array}{l}\text { HUVEC } \\
\text { MSC }\end{array}$ & $3 D$ & $\begin{array}{l}\text { Col-1 + } \\
\text { fibrin }\end{array}$ & $\begin{array}{l}\text { EGM-2, } \\
\text { DMEM }\end{array}$ & $\begin{array}{l}\text { Increasing fibrin } \\
\text { concentration increased } \\
\text { vascular morphogenesis. }\end{array}$ & $\begin{array}{l}\text { Tissue } \\
\text { engineering }\end{array}$ & [110] \\
\hline BAEC & $2 \mathrm{D}$ & Matrigel $^{\circledR}$ & $\begin{array}{l}\text { DMEM, } \\
\text { VEGF, rGAL- } \\
8\end{array}$ & $\begin{array}{l}\text { GAL-8 promoted endothelial } \\
\text { cell migration and capillary } \\
\text { formation. }\end{array}$ & Cancer research & [111] \\
\hline RAEC & $2 \mathrm{D}$ & Matrigel $^{\circledR}$ & $\begin{array}{l}\text { DMEM, } \\
\text { VEGF, } \\
\text { roxarsone }\end{array}$ & $\begin{array}{l}\text { Roxarsone promoted } \\
\text { vascular formation in vitro. }\end{array}$ & Cancer research & [112] \\
\hline $\begin{array}{l}\text { EVC } \\
\text { Pericytes }\end{array}$ & $3 D$ & $\begin{array}{l}\text { Col-1, HA- } \\
\text { hydrogel }\end{array}$ & EGM-2 & $\begin{array}{l}\text { Pericytes enhanced network } \\
\text { formation and stability. }\end{array}$ & $\begin{array}{l}\text { Regenerative } \\
\text { medicine }\end{array}$ & [113] \\
\hline $\begin{array}{l}\text { CC-SMC } \\
\text { CJ-EC }\end{array}$ & $3 D$ & Fibrin & M199 & $\begin{array}{l}\text { Co-culture with SMCs } \\
\text { increased length and density } \\
\text { of vessels formed by } \\
\text { endothelial cells. }\end{array}$ & $\begin{array}{l}\text { Tissue } \\
\text { engineering }\end{array}$ & [115] \\
\hline $\begin{array}{l}\text { HUVEC } \\
\text { HDF }\end{array}$ & $2 \mathrm{D}$ & Matrigel $^{\circledR}$ & EGM-2 & $\begin{array}{l}\text { Capillary-like network } \\
\text { formed only in co-cultures } \\
\text { with HDF. }\end{array}$ & $\begin{array}{l}\text { Tissue } \\
\text { engineering, } \\
\text { regenerative } \\
\text { medicine }\end{array}$ & [116] \\
\hline $\begin{array}{l}\text { HMVEC } \\
\text { HDF }\end{array}$ & $2 \mathrm{D}$ & Col-1 & EBM-2 & $\begin{array}{l}\text { Revealed Collagen binding } \\
\text { to specific integrin on } \\
\text { endothelial cells activating } \\
\text { tube formation pathways. }\end{array}$ & $\begin{array}{l}\text { Developmental } \\
\text { studies }\end{array}$ & [118] \\
\hline HUVEC & $2 \mathrm{D}$ & $\begin{array}{l}\text { Matrigel }^{\circledR}, \\
\text { PEG }\end{array}$ & $\begin{array}{l}\text { Medium } \\
200\end{array}$ & $\begin{array}{l}\text { Matrix thickness and } \\
\text { stiffness affected vascular } \\
\text { cord length and network } \\
\text { density. }\end{array}$ & $\begin{array}{l}\text { Tissue } \\
\text { engineering }\end{array}$ & [119] \\
\hline $\begin{array}{l}\text { BEC } \\
\text { LEC }\end{array}$ & $\begin{array}{l}2 \mathrm{D} \text { or } \\
3 \mathrm{D}\end{array}$ & Fibrin & $\begin{array}{l}\text { EGM-2, } \\
\text { VEGF-C }\end{array}$ & $\begin{array}{l}\text { BEC and LEC formed } \\
\text { separate networks, both }\end{array}$ & $\begin{array}{l}\text { Tissue } \\
\text { engineering, drug }\end{array}$ & [120] \\
\hline
\end{tabular}


ASC

RBMVEC 3D Col-1 DMEM

ASC requiredco-culture with

ASCs.

Stimulation of Notch 1

pathway enhanced

vasculogenesis. screening

Regenerative

medicine

[122]

Abbreviations: Ang-1, angiopoietin-1; ASC, adipose-derived stem cells; BAEC, bovine aortic endothelial cells; $\mathrm{BEC}$, blood vascular endothelial cells; CC-SMC, canine carotid artery-derived smooth muscle cells; CJ-EC, canine jugular vein-derived endothelial cells; bFGF, basic fibroblast growth factor; BME, basement membrane extract (Trevigen); Col-1, collagen type-I; CS, calcium silicate; DMEM, Dulbecco's modified Eagle's medium; EBM, endothelial basal medium; ECGS, endothelial cell growth supplement (Promocell); ECM, extracellular matrix; EGM, endothelial growth medium; EVCs, early vascular cells;F12, Ham's F-12 medium; Fbn, fibronectin; HAhydrogel, hyaluronic acid based hydrogel; HBMSC, human bone marrow-derived mesenchymal stem cells; HDF, human dermal fibroblasts; hES-MC, human embryonic stem cell derived mesenchymal cells; HGF, hepatocyte growth factor; HMVEC, human dermal microvascular endothelial cells; HUVEC, human umbilical vein endothelial cells; LEC, lymphatic endothelial cells;M199, medium 199 (Lonza); MSC, mesenchymal stem cells; NHLF, human normal lung fibroblasts; PEG, polyethylene glycol hydrogel;RAEC, rat aortic endothelial cells; RBMVEC, rat brain microvascular endothelial cells;rGAL8, recombinant galectin-8; RPMI, Roswell Park Memorial Institute medium (Gibco); SF, skin fibroblasts; TGF- $\beta$, transforming growth factor beta; VEGF, vascular endothelial growth factor; WIF-1, Wnt inhibitory factor-1.

\subsection{Limitations of endothelial cell culture}

Endothelial cell cultures are relatively easy to maintain. However, there are certain limitations which need to be considered while carrying out endothelial culture. A blood vascular network constitutes a number of vessel types, from large vessels to micro vessels, and each vessel type has its own unique properties (including endothelial cell subtypes). Therefore it is challenging to attempt to recapitulate the formation of different vessel types using a homogeneous endothelial cell population [123]. Primary endothelial cell cultures are usually derived from terminally differentiated tissues; these cells have limited proliferative and regenerative capacity, and a short life span in vitro [124, 125].

Endothelial cells derived from different sites within the same tissue express different genes and respond differently to the same pro- or anti- angiogenic factors [126]. This supports the idea of functional subtypes among endothelial cells. Endothelial cells can be immortalised; however, this may change their behaviour and response to stimuli [127]. Immortalised endothelial cells may alter their gene expression and physiological properties with repeated passaging in vitro, resulting in loss of vasculogenesis efficiency [127]. The non-endothelial cell types that support in vitro vascular network formation from endothelial cells (e.g. fibroblasts), may represent an undesirable cell type if the resultant culture is to be used for tissue engineering [100]. 


\section{Use of stem cells for in vitro vasculogenesis}

In recent years, stem cells have increasingly been used to develop vascular cultures; this is because stem cells have several advantages over terminally differentiated endothelial cells [19]. Stem cells are multipotent or pluripotent in nature, they show self-renewal, and their differentiation along various cell lineages can be manipulated by fine-tuning the culture conditions [19]. A few examples of the stem cells that can be used for endothelial, and ultimately vascular, differentiation are summarized in Table 3. Three main stem cell types used are: (i) embryonic stem cells (ESCs) [128], (ii) induced pluripotent stem cells (iPSCs) [129] and(iii) mesenchymal stem cells (MSCs) [130].

In addition, endothelial progenitor cells (EPCS), which originate in the bone marrow and contribute to the formation of new blood vessels in adults, are also useful in the study of in vitro vasculogenesis [125]. The differentiated endothelial cells arising from stem cells directly undergo vasculogenesis because of the presence of other cell types that have also differentiated from the stem cells.Alternatively, the endothelial cells can be isolated from the stem cell culture, without the unwanted additional cell types, and used for vascular morphogenesis (either in pure culture or co-culture with defined cell types) [113].

One of the advantages of using ESCs is that they can differentiate into multiple vascular cell lineages simultaneously in culture. In principle, these different lineages can contribute to the newly-formed vessels (neovessels) in a way that closely resembles the in vivo vasculogenesis in early embryos $[19,131]$. Endothelial differentiation and vascular morphogenesis in ESCs is controlled by culture conditions (such as the presence of growth factors in the medium and the use of feeder layers of stromal cells, or a substratum consisting of a natural or synthetic hydrogel $[131,132])$.

One approach to inducing the differentiation of ESCs in culture is to allow them to first aggregate into spherical cell masses, called embryoid bodies (EBs), in suspension culture[133]. The use of EBs as an intermediate step is common when ESCs are cultured for vascular differentiation (Table 3) [134]. In the absence of anti-differentiation factors (e.g. leukaemia inhibitory factor in mouse and feeder cell layer in human), ESCs differentiate into EBs consisting of mesodermal, ectodermal and endodermal lineages, similar to early embryogenesis [135]. In 2D (adherent) cultures the EB cells tend to proliferate and give rise 
to undesired cell types such as fibroblasts [133]. By contrast, in 3D culture (suspension or gels), the proliferation of EB cells is limited, allowing greater control of the differentiation of the desired cell type [133]. Significant effects of different factors, such as culture substrate (collagen type-IV or fibronectin), cell seeding density, concentration of VEGF and FGF in medium, and culture duration, have been observed on the endothelial differentiation in human, mouse and zebrafish ESC culture $[88,136]$. Similarly, TGF- $\beta$ has been identified to induce vascular differentiation in human ESCs [137].

Table 3. The use of stem cell technology for endothelial differentiation and vascular development.

\begin{tabular}{|c|c|c|c|c|c|c|}
\hline $\begin{array}{l}\text { Stem } \\
\text { cell type }\end{array}$ & $\begin{array}{l}\text { Culture } \\
\text { strategy }\end{array}$ & $\begin{array}{l}\text { ECM } \\
\text { Substrate }\end{array}$ & $\begin{array}{l}\text { Medium } \\
\text { additives }\end{array}$ & Main findings & Possible applications & Ref. \\
\hline mESC & EB static 3D & Col-1 & $\begin{array}{l}\text { IMDM, EPO, } \\
\text { VEGF, bFGF, }\end{array}$ & $\begin{array}{l}\text { RSK and TTK protein kinases } \\
\text { modulated vascular } \\
\text { formation. }\end{array}$ & $\begin{array}{l}\text { Cancer research, } \\
\text { drug screening }\end{array}$ & [128] \\
\hline mESC & EB static 3D & Matrigel ${ }^{\circledR}$ & $\begin{array}{l}\text { aMEM, } \\
\text { VEGF }\end{array}$ & $\begin{array}{l}\text { Reporter proteins in vascular } \\
\text { cells allowed track of } \\
\text { vascular development. }\end{array}$ & $\begin{array}{l}\text { Developmental } \\
\text { studies }\end{array}$ & [138] \\
\hline mESC & Static 3D & Col-1 & $\begin{array}{l}\text { IMDM, } \\
\text { VEGF, bFGF }\end{array}$ & $\begin{array}{l}\text { EB formation and angiogenic } \\
\text { sprouting. }\end{array}$ & Drug screening & [139] \\
\hline mESC & Static 2D & Gelatin & $\begin{array}{l}\text { DMEM, } \\
\text { VEGF }\end{array}$ & $\begin{array}{l}\text { Endothelial differentiation } \\
\text { and vascular network } \\
\text { formation. }\end{array}$ & $\begin{array}{l}\text { Developmental } \\
\text { studies, drug } \\
\text { screening }\end{array}$ & {$[140]$} \\
\hline mESC & EB static 2D & Col-1 & $\begin{array}{l}\text { DMEM, } \\
\text { VEGF }\end{array}$ & $\begin{array}{l}\text { VEGF receptors are involved } \\
\text { in tip cell selection and } \\
\text { sprouting. }\end{array}$ & $\begin{array}{l}\text { Developmental } \\
\text { studies }\end{array}$ & [141] \\
\hline mESC & EB static 3D & Col-1 & $\begin{array}{l}\text { IMDM, EPO, } \\
\text { VEGF, bFGF }\end{array}$ & $\begin{array}{l}\text { Culture strategy, ECM } \\
\text { substrate and growth factors } \\
\text { effected vascular } \\
\text { differentiation. }\end{array}$ & Drug screening & {$[142]$} \\
\hline hESC & Static 2D & Matrigel $^{\circledR}$ & $\begin{array}{l}\text { EGM-2, } \\
\text { BMP-4 }\end{array}$ & $\begin{array}{l}\text { BMP-4 increased vascular } \\
\text { differentiation. }\end{array}$ & $\begin{array}{l}\text { Developmental } \\
\text { studies, angiogenic } \\
\text { therapy }\end{array}$ & [143] \\
\hline hESC & $\begin{array}{l}\text { Static non- } \\
\text { adherent }\end{array}$ & & $\begin{array}{l}\text { Knockout } \\
\text { DMEM }\end{array}$ & $\begin{array}{l}\text { Spontaneous endothelial } \\
\text { differentiation and Vascular } \\
\text { sprouting. }\end{array}$ & $\begin{array}{l}\text { Tissue engineering, } \\
\text { regenerative } \\
\text { medicine }\end{array}$ & [144] \\
\hline miPSC & EB static 3D & Col-1 & $\begin{array}{l}\text { DMEM, } \\
\text { VEGF }\end{array}$ & $\begin{array}{l}\text { TP73 gene regulates } \\
\text { endothelial differentiation } \\
\text { and vascular network } \\
\text { formation. }\end{array}$ & Cancer research & {$[145]$} \\
\hline hiPSC & Static 2D & Fbn & $\begin{array}{l}\text { IMDM, } \\
\text { VEGF, bFGF }\end{array}$ & $\begin{array}{l}\text { Formation of vessel-like } \\
\text { structures. }\end{array}$ & $\begin{array}{l}\text { Tissue engineering, } \\
\text { regenerative } \\
\text { medicine }\end{array}$ & [146] \\
\hline hAFSC & $\begin{array}{l}\text { Static } \\
2 D\end{array}$ & Matrigel $^{\circledR}$ & $\begin{array}{l}\text { EGM-2, } \\
\text { VEGF }\end{array}$ & $\begin{array}{l}\text { EGM and VEGF promoted } \\
\text { endothelial differentiation } \\
\text { and vascular formation. }\end{array}$ & $\begin{array}{l}\text { Tissue engineering, } \\
\text { angiogenic therapy }\end{array}$ & [130] \\
\hline hAFSC & $\begin{array}{l}\text { Flow* } \\
2 \mathrm{D}\end{array}$ & Matrigel $^{\circledR}$ & EGM-2 & $\begin{array}{l}\text { Shear stress promoted } \\
\text { endothelial differentiation } \\
\text { and vascular cord formation. }\end{array}$ & $\begin{array}{l}\text { Regenerative } \\
\text { medicine }\end{array}$ & {$[147]$} \\
\hline hTMSC & Static 3D & Fibrin & EGM-2 & $\begin{array}{l}\text { TMSCs promoted and } \\
\text { stabilized vessel formation } \\
\text { from endothelial cells. }\end{array}$ & $\begin{array}{l}\text { Tissue engineering, } \\
\text { regenerative } \\
\text { medicine }\end{array}$ & [148] \\
\hline
\end{tabular}


Abbreviations: aMEM, alpha-minimal essential medium (Cellgro); bFGF, basic fibroblast growth factor; BMP-4, bone morphogenetic protein-4; Col-1, collagen type-I; DMEM, Dulbecco's modified Eagle's medium; EB, embryoid body intermediate; ECM, extracellular matrix; EGM, endothelial growth medium (Cambrex or Clonetics); EPO, erythropoietin; Fbn, fibronectin; Flow*, on the margins of the bottom of a flask on an orbital shaker; hAFSC, human amniotic fluid-derived stem cells; hESC, human embryonic stem cells; IMDM, Iscove's modified Dulbecco's medium; mESC, mouse embryonic stem cells; miPSC, mouse induced pluripotent stem cells; RSK, ribosomal S6 kinase; Static, static replacement culture; TP73, tumor protein-73; TTK, threonine and tyrosine kinase; VEGF, vascular endothelial growth factor.

Another important stem cell type, similar to ESCs in pluripotency and differentiation events, is the iPSCs[149]. An advantage of iPSCs is that they can be generated by genetic reprogramming of any adult somatic cell population, and therefore raise fewer ethical concerns compared to ESCs [19]. Endothelial differentiation in iPSCs can be induced by applying similar methods used for differentiation of ESCs [150]. Furthermore, gene expression in endothelial cells derived from ESCs and iPSCs is very similar [150]. MSCs are multipotent stem cells residing in adult tissues; they have limited differentiation potential compared to ESCs and iPSCs[19]. Endothelial differentiation in human amniotic fluid derived MSCs has been shown to be inducible by VEGF [130]. MSCs derived from various tissues (bone marrow, hair follicle, adipose tissue and muscles) have been used for vascular regeneration studies reviewed in Ref. [19]. In some studies the MSCs have been reported to promote and stabilize vascular network formation from HUVECs (Table 2).

In addition to the use of pluripotent and multipotent stem cells for endothelial differentiation and in vitro vasculogenesis, the unipotent EPCs also have the ability to differentiate into mature endothelial cells and form vascular tubes in culture [125]. The advantage of EPCs for culturing vascular networks is that these cells can be easily obtained from adult tissues such as peripheral blood [19]. In vitro studies have shown that the early EPCs do not directly undergo vascularization, but release factors to stimulate angiogenesis in distantly-cultured endothelial cells in a transwell[125]. Co-culture with MSCs has been proven to enhance vascular formation from EPCs both in vitro and after implantation in vivo $[151,152]$.

\subsection{Issues and drawbacks with stem cell culture}

Although stem cell technology has several advantages for vascular engineering and regenerative therapy, there are some limitations to its use [19]. Thus, while ESCs have been extensively studied in laboratory animals such as mouse and rats, and stable cell lines have 
been developed from these animals, the technique has been proven less successful for other species such as cattle, goat and dogs [149]. Furthermore, the very complexity of vascular differentiation from ESCs means that the growth factors necessary to support the generation and maintenance of multiple cell types need to be laboriously optimised [153]. Furthermore, the use of human ESCs for research raise ethical concerns [19].

ESCs and iPSCs are both pluripotent, and therefore it is challenging to direct the differentiation towards a specific lineage, and to obtain high quality pure cell cultures [149]. The iPSCs are developed by transfection of somatic cells with pluripotency genes; however, the efficiency of the process is very low (less than 1\%) [154]. The iPSCs (in contrast to ESCs) are derived from adult differentiated cells by de-differentiation. Then, if re-differentiated into a specific cell type, they attain some of the characteristics of that cell type but are not identical to their normal counterparts [154]. Other issues with stem cells is that the isolation of MSCs from adult tissues requires invasive surgical procedures, and only yields small numbers of cells; the proliferation of these cells is also limited in vitro[155]. Furthermore, the MSCs isolated from different tissues or life stages are not the same, and therefore have different culture requirements and angiogenic potentials [156].

The isolation and culture methods for EPCs are only relatively recently developed (Asaharaet al., 1997 [157]). For this reason, there is no standard protocol among researchers. It should be noted that there are no specific markers for EPCs because many of the genes expressed by EPCS are also expressed in hematopoietic progenitors [158]. Similar to the iPSCs and MSCs, the number of EPCs found in isolated adult tissue cells is very low, and this greatly limits their study [19]. Finally, analysis of EPCs in long-term culture has shown that the late passage cells ( 45 days after the initiation of the primary culture) have changed morphology, reduced their proliferation rate, show high $\beta$-galactosidase expression and loss of vascular network formation ability, compared to the early passaged cells [159].

\section{Use of tissue explants for in vitro angiogenesis}

An important strategy for vascular morphogenesis in vitrois to stimulate the growth of the blood vessels existing in isolated sections or fragments of specific tissues[127].The development of a well-defined blood vascular network requires the incorporation of 
multiple cell types both in vivo and in vitro, as discussed in the previous sections. The use of tissue explants is important in this context, because these explants already contain multiple cell types, and the angiogenesis stimulated in these cultures closely represents the corresponding process in vivo[127].Furthermore, tissue explant experiments are relatively easy to perform and allow a large number of cultures to be derived from a single tissue sample[160].

Various tissue explants have been shown to have the ability to develop vascular sprouts in vitro (Table 4). Examples include cross sections of aorta called aortic rings [161]; metatarsal bones [162]; retina fragments [163]; choroid-sclera fragments [164]; and adipose tissue [165]. In most cases, the tissues for explant preparation are isolated from developing rodent embryos or neonates. Tissue explants from other species such as chick embryo aortic arch [166], rabbit aorta [167] and pig carotid artery [168] have also been adapted for sprouting angiogenesis. Furthermore, angiogenic sprouting has also been reported from human tissue explants e.g. adipose tissue [165], aortic explants from aborted embryos [169], placental explants $[170,171]$ and umbilical artery rings [172].

Explant cultures are usually established in a 3D gel matrix in the presence of angiogenic growth factors, and are examined for microvessel outgrowth (vascular sprouting)[127, 173]. The aortic ring model from various species is the most commonly used explant for studying in vitro angiogenesis (Table 4). The stimulatory effect of various factors, such as angiogenic growth factors (especially VEGF) and ECM components, on the growth of vascular sprouts from aortic ring have been extensively studied, reviewed in Ref. [174]. Recentlydeveloped explant cultures, using fetal metatarsals from mice, have shown advantages over the aortic ring model, in that they do not require a 3D matrix and exogenous growth factors for vascular sprouting [162].In general, explant cultures can serve as an intermediate between the endothelial cell culture on the one hand, and in vivo models on the other. They are also thought to be more reliable for studying the mechanisms of angiogenesis andtesting the role of regulatory factors [175].

\subsection{Limitations of explant cultures}

Besides the advantages of explant cultures, certain limitations need to be addressed before the technique can be fully accepted for research in tissue engineering and regenerative 
medicine. The mouse aortic ring model shows significant variability in microvessel sprouting from explants isolated from different age and strain of animals [176]. Variability in outcome has also been reported using explants isolated from different vessel types (artery or vein) of the same individual animal [177]. The vascular sprouts in the aortic ring model regress over time in culture (with peak sprouting between days 6 and 7), and this limits the analysis time and increases variability in results with culture duration [161]. Furthermore, the aortic rings are derived from large vessels, and therefore do not truly represent in vivo angiogenesis, which is a microvascular process [127].

Table 4. Tissue explants used for sprouting angiogenesis in vitro.

\begin{tabular}{|c|c|c|c|c|c|c|}
\hline $\begin{array}{l}\text { Tissue } \\
\text { explant }\end{array}$ & $\begin{array}{l}\text { Culture } \\
\text { strategy }\end{array}$ & $\begin{array}{l}\text { ECM } \\
\text { Substrate }\end{array}$ & $\begin{array}{l}\text { Medium } \\
\text { additives }\end{array}$ & Main findings & $\begin{array}{l}\text { Possible } \\
\text { applications }\end{array}$ & Ref. \\
\hline $\mathrm{mAR}$ & Static 3D & Col-1 & $\begin{array}{l}\text { Opti-MEM, } \\
\text { VEGF }\end{array}$ & $\begin{array}{l}\text { VEGF and collagen } \\
\text { increased vessel sprouting. }\end{array}$ & Drug screening & [161] \\
\hline mAR & Static 3D & Col-1 & $\begin{array}{l}\text { MCDB131, } \\
\text { VEGF }\end{array}$ & $\begin{array}{l}\text { Age of the mouse inversely } \\
\text { affected vascular sprouting } \\
\text { from explant. }\end{array}$ & Drug screening & [178] \\
\hline mAR & Static 3D & Col-1 & ESFM & $\begin{array}{l}\text { Endostatin inhibited } \\
\text { vascular sprouting by } \\
\text { modulating endothelial } \\
\text { cell-ECM interaction. }\end{array}$ & Cancer research & [179] \\
\hline rAR & Static 3D & Matrigel ${ }^{\circledR}$ & EGM-200 & $\begin{array}{l}\text { Ascorbate inhibited } \\
\text { sprouting angiogenesis. }\end{array}$ & Cancer research & [180] \\
\hline hUAR & Static 3D & BME & EGM-2 & $\begin{array}{l}\text { Capillary spouting upon } \\
\text { VEGF stimulation. }\end{array}$ & $\begin{array}{l}\text { Cancer research, } \\
\text { drug screening }\end{array}$ & {$[172]$} \\
\hline CAA & Static 2D & Matrige $^{\circledR}$ & bFGF, VEGF & $\begin{array}{l}\text { Chemical compound } \\
\text { releasing nitric oxide } \\
\text { inhibited angiogenesis }\end{array}$ & $\begin{array}{l}\text { Cancer research, } \\
\text { drug screening }\end{array}$ & [181] \\
\hline mAT & static 3D & Col-1 & $\begin{array}{l}\text { MCDB131, } \\
\text { VEGF }\end{array}$ & Angiogenic sprouting. & Drug screening & [182] \\
\hline hAT & Static 2D & Matrigel $^{\circledR}$ & $\begin{array}{l}\text { EBM-2, } \\
\text { EGM-2MV }\end{array}$ & $\begin{array}{l}\text { Angiogenic capacity } \\
\text { reflected donor's } \\
\text { physiology. }\end{array}$ & $\begin{array}{l}\text { Angiogenic therapy, } \\
\text { drug screening }\end{array}$ & {$[165]$} \\
\hline $\mathrm{mRE}$ & Static 2D & PTFE & $\begin{array}{l}\text { DMEM, } \\
\text { VEGF }\end{array}$ & $\begin{array}{l}\text { VEGF stimulated vascular } \\
\text { sprouting. }\end{array}$ & Drug screening & [183] \\
\hline $\mathrm{mRE}$ & Static 3D & Fibrin & $\begin{array}{l}\text { DMEM, } \\
\text { VEGF }\end{array}$ & $\begin{array}{l}\text { VEGF stimulated sprouting } \\
\text { angiogenesis in a dose } \\
\text { dependent manner. }\end{array}$ & Drug screening & [184] \\
\hline $\mathrm{mMT}$ & Static 2D & $\begin{array}{l}\text { Gelatin OR } \\
\text { col-1 }\end{array}$ & $\alpha \mathrm{MEM}$ & $\begin{array}{l}\text { Vascular sprouting } \\
\text { occurred without } \\
\text { additional growth factors. }\end{array}$ & $\begin{array}{l}\text { Developmental } \\
\text { studies, drug } \\
\text { screening }\end{array}$ & {$[162]$} \\
\hline $\mathrm{mMT}$ & Static 2D & & $\begin{array}{l}\text { aMEM, } \\
\text { VEGF }\end{array}$ & $\begin{array}{l}\text { VEGF recovered the } \\
\text { impaired vascular } \\
\text { sprouting in endoglin } \\
\text { deficient explants. }\end{array}$ & $\begin{array}{l}\text { Diseases modelling, } \\
\text { drug screening }\end{array}$ & [185] \\
\hline $\mathrm{mPE}$ & Static 2D & Col-1 & $\begin{array}{l}\text { M199, VEGF, } \\
\text { bFGF }\end{array}$ & $\begin{array}{l}\text { Isoforms of VEGF } \\
\text { differentially stimulated } \\
\text { vascular sprouting. }\end{array}$ & $\begin{array}{l}\text { Developmental } \\
\text { studies }\end{array}$ & [186] \\
\hline
\end{tabular}


Abbreviations: $\alpha M E M$, alpha-minimal essential medium; bFGF, basic fibroblast growth factor; BME, basement membrane extract (BD Biosciences); cAA, chick aortic arch; Col-1, collagen type-I; DMEM, Dulbecco's modified Eagle's medium; EBM, endothelial basal medium (Lonza); ECM, extracellular matrix; EGM-MV, endothelial growth medium microvascular; EGM, endothelial growth medium (Cascade Biologics); ESFM, endothelial serum-free medium (Life Technologies); hAT, human adipose tissue explant; hUAR, human umbilical arterial ring; M199, medium 199 (Gibco); mAR, mouse aortic ring; mAT, mouse adipose tissue explant; MCDB131, basal medium (Invitrogen); mMT, mouse metatarsal explant; mPE, mouse proepicardium explant; mRE, mouse retinal explant; Opti-MEM, minimal essential reduced-serum medium (Gibco); PTFE, polytetrafluroethylene membrane; rAR, rat aortic ring; Static, static replacement culture; VEGF, vascular endothelial growth factor.

Tissues containing microvascular networks (e.g. adipose tissue and retina) can be used for explant preparation. However, these tissues are more difficult to isolate and, like the aortic explant, show variability between experiments [163]. The high levels of capillary sprouting observed in adipose tissue explant cultures are in many senses an advantage; however they do make it difficult to identify all the sprouts individually and interpret the results [165]. Similarly, angiogenic sprouts from fetal mouse metatarsal explants present microvascular features; however, their isolation and culture procedures also require advanced technical skills, which are key to the reproducibility of the research[162]. Finally, the metatarsal and chick aortic arch explants are isolated from developing embryos and have high proliferative capacity; therefore, angiogenesis in these models does not represent the in vivo situation in adults [127].

\section{Zebrafish: a new model species for studying in vivo}

\section{vasculogenesis and angiogenesis}

The zebrafish is a freshwater teleost fish [187] that is emerging as a model of choice for studying vasculogenesis and angiogenesis[188]. The embryos and larvae are often used in these studies because of their external fertilization, optical transparency at early stages, and the ease of exposure to test substances (by simply adding the compound to the swimming water) [189]. Furthermore, the genome comparison study has revealed that there is at least one orthologue in zebrafish genome for more than $70 \%$ of human protein coding genes [31]. Vascular development and function in zebrafish are relatively conserved, compared to the same processes in other vertebrates [188].

The embryos develop a simple vascular system with circulating blood as early as 24 hours post fertilization (hpf) [37]. Vascular development can be directly observed non-invasively in 
the living, transparent embryo [28]. Enhanced visualization of vascular development can be achieved by injecting fluorescent micro particles into the blood stream, or by using transgenic lines such as kdrl:GFP and fli:GFPthat express green fluorescent protein (GFP) in vascular cells [28].

For these and other reasons, vascular development in zebrafish - from early differentiation of angioblasts to the maturation of blood vessels-has been extensively studied [32, 37, 190, 191]. Studies have shown similar angiogenic responses to the test substance irisin, in zebrafish embryos in vivo, and in HUVECs in vitro[192]. In another example, the genetic mutation (gridlock), which causes aortic malformations and congenital heart defects in humans, showed similar phenotypic effects in zebrafish [193]. Zebrafish have been successfully utilized to model several human vascular diseases reviewed in Ref.[32].

Similarly, a zebrafish in vivo xenograft model has been developed to study human carcinomas [194]. These studies have shown successful invasion, metastasis and extravasation of various human tumorcells in zebrafish embryos and adults [194]. It has been demonstrated that the transplantation of human WM-266-4 melanoma cells and breast adenocarcinoma cells in zebrafish embryos induced angiogenesis in the host vasculature; this led to the formation and infiltration of neovessels into the tumor masses[195, 196].Other examples of human carcinomas studied in zebrafish include breast cancer bone metastasis [197], uveal melanoma [198] and retinoblastoma [199].

The zebrafish possesses remarkable regenerative capacity in several organs (including the caudal fin and heart $[200,201])$ which makes it a useful model for studying regeneration [202]. The regeneration of organs also involves the regeneration of blood vessels, and therefore the regenerative capacity of zebrafish is also important for vascular regeneration studies [28].

\subsection{Zebrafish transgenic reporter lines for vascular studies}

Several transgenic lines have been developed for zebrafish which express fluorescent proteins under vascular cell specific promoters [28]. These transgenic lines allow the tracking of the differentiation, proliferation and migration of individual cells during vascular developmentin vivo and in vitro [28]. Moreover, different transgenes can be combined in the same embryo,as was done with a line (scl-PAC:GFP) expressing fluorescent proteins in both 
endothelial and blood cells; that line permitted the observation of the development of the vascular system and blood flow simultaneously [203].

The most important transgenic line that we are utilizing to study vascular development in zebrafish is the kdrl:GFP line (Figure 3A). This transgenic line isalso known as $T g(k d r: e G F P)$ or $T g(f l k 1: e G F P)$ [204]. In this line, GFP is specifically expressed in endothelial cells under the control of the VEGFR2 or kdr-like gene [204]. The kdrl:GFP line allows high resolution analysis of single cell migration and vascular development in living embryos [204].The utility of $k d r l: G F P$ zebrafish embryos has been confirmed as a high-throughput model for screening the effect of toxic compounds on vascular development[205].

Other transgenic zebrafish lines are available for vascular studies, although they have some limitations. For example, In Tg(Tie2:eGFP) the GFP expression is relatively weak in the vascular cells[206]. Similarly, in Tg(fli1:eGFP) the GFP is expressed in certain non-vascular cells which interferes with the results especially in the head region of the embryo [204]. Furthermore, studies on $T g(f l i 1: e G F P)$ have shown changes in the gene expression of a number of genes, compared to the wild type embryos, which may affect the results while using transgenic zebrafish for experiments [207].

In summary, zebrafish is a high-throughput, easily quantifiable, fast developing and relatively inexpensive in vivo model for vascular studies. However, there are some drawbacks associated with this model. For example, the relevance of zebrafish embryo model to understand human angiogenesis is questioned, as there is a large evolutionary time difference between the two species [175]. Therefore, preclinical drug screening in zebrafish should always be followed by validation in mammalian models beforegoing to clinical trials [28].

\section{Future prospects for using zebrafish cells for in vitro vasculogenesis and angiogenesis}

In principle, many of the techniques discussed in the previous sections for in vitrovasculogenesis and angiogenesis (using mammalian endothelial cells, ESCs and tissue explants), can also be adapted for use in the zebrafish model. With the availability of primary embryonic cells due to high fecundity of the species, and easy cell isolation procedures, the 
drawbacks associated with adapted cell lines can be avoided [208]. In addition to the above mentioned characteristics, zebrafish also possess specific desirable features for in vitro applications.

\subsection{Cell culture techniques in zebrafish}

The external fertilization andlarge number of fast developing embryos, allow easy harvesting of large numbers of cells and quantities of tissues from different developmental stages[209]. Zebrafish cells grow at a lower temperature $\left(26-28^{\circ} \mathrm{C}\right)$ than chick and mouse cells and do not usually require a $\mathrm{CO}_{2}$-enriched atmosphere [209]. These properties allow zebrafish cells to be grownat room temperature, although the use of a simple incubator is recommended to help maintain sterile conditions[209]. The protective covering of the chorion, which is present until hatching at around $48 \mathrm{hpf}$, partly isolates the embryos from the environment[210]. This is important for in vitro studies because it maintains the embryos in an aseptic condition[211].

To harvest sterile cells or tissues from zebrafish embryos it is necessary to decontaminate the surface of the chorion. Using this approach, it is possible to isolate and culture sterile cells from blastula (3 hpf) or gastrula (24 hpf) stage embryos [209, 212].In a recent study, we have shown that embryos with a chorion decontaminated at $24 \mathrm{hpf}$ could be further cultured to 5 dpfunder aseptic conditions [173]. The tissues and cells isolated from these embryos were successfully maintained free of contamination for eight days in culture.

\subsection{Zebrafish embryonic stem cells}

As is the case with mouse and human ESCs, it is possible to maintain zebrafish ESCs in a pluripotent state inlong-term culture[213].In zebrafish and medaka, the ESCs can be derived from the embryo before the blastocyst stage; these cells may possess a higher degree of pluripotency (and even totipotency), compared to mammalian ESCs derived from blastocysts[214]. When differentiation inhibition factors are depleted in the culture medium, the zebrafish ESCs have the ability to undergo differentiation into a range of specialized cell types [212].The spontaneous differentiation of zebrafish ESCs into neuron-like cells, musclelike cells, embryonic carcinoma-like cells and fibroblast-like cellshas been demonstrated $[209,212,215]$. However, little is known about the condition needed to induce specific differentiation in ESCs from zebrafish. 

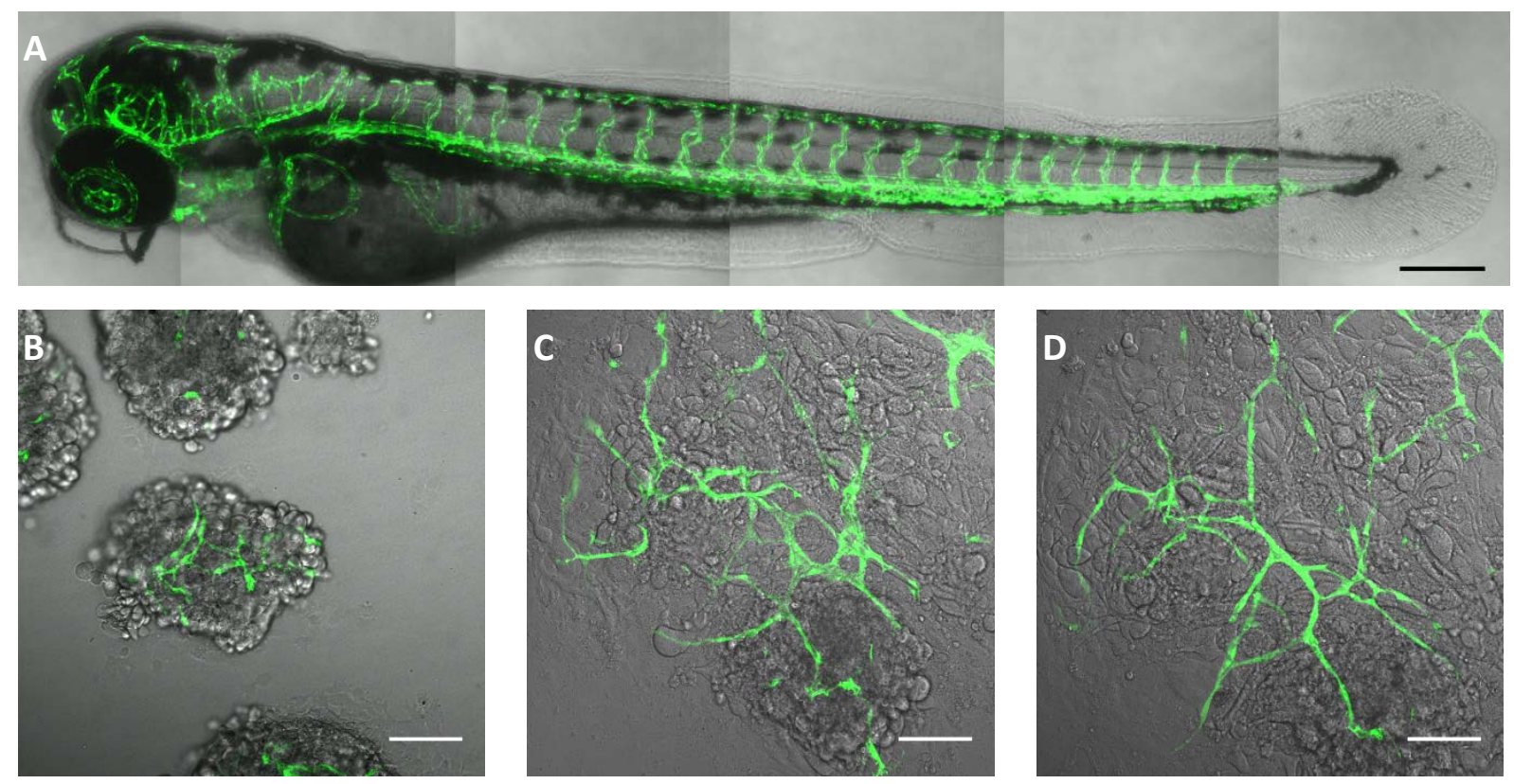

Figure 3: Confocal images of transgenic zebrafish kdrl:GFP whole embryo (A) and EB culture (B-D). (A) A 5 dpf $k d r l: G F P$ embryo showing florescent endothelial cells forming blood vessels. Scale bar, $200 \mu \mathrm{m}$. (B, C and D) Developing embryoid body on subsequent days of culture (day 1, day 6 and day 8 , respectively) on a mixture of collagen type-I, Geltrex ${ }^{\mathrm{TM}}$ and fibrin substratum, showing the development of vascular network-like structures from $k d r l: G F P^{+}$endothelial cells. Scale bars, $100 \mu \mathrm{m}$.

The induction of myogenic differentiation in zebrafish primary ESCs has been shown by culturing these cells on a laminin substratum, in medium containing insulin [216], FGF [217] or sonic hedgehog protein [218]. In another study, the seeding density (between 1 and $2 \times$ $10^{4}$ cells $/ \mathrm{cm}^{2}$ ) of zebrafish primary ESCs, co-culture with a zebrafish fibroblast-like cell line (ZF4) and medium supplementation with insulin, were found to induce cardiomyocyte differentiation [219]. Similarly, an increase in the generation of primordial germ cellresembling-cells was found in zebrafish blastocyst cell cultures after the addition of BMP4, EGF and retinoic acid to the medium [220]. Furthermore, the use of FGF and VEGF have been shown to increase differentiation towards the endothelial cell lineage in zebrafish blastocyst cells [221].

Zebrafish blastocyst cells aggregate into EBs in culture. We have shown that the percentage of endothelial-like $\left(k d r l: G F P^{+}\right)$cells in EBs is increased by culturing them in suspension (i.e. hanging drop culture)rather than in adherent culture, and by adding endothelial growth supplements, including VEGF, to the medium [136]. We found that the $k d r l: G F P^{+}$cells in EB culturesform vascular network-like structures on hydrogel substrates (Figure 3B-D). 


\subsection{Cultures of specialised zebrafish cell types}

Attempts have been made to develop cultures of specialised cell types using progenitor cells isolated from zebrafish embryos.In one study, neural crest cells, isolated from dissociated 14 hpf (10-somite stage) embryos, were maintained in culture [222]. These cells were shown to proliferate, migrate and differentiate into neurons, chondrocytes and glial cells in vitro[222]. Strategies have also been described for the culture of primary neurons from developing brain and spinal cord cells of zebrafish embryos [223]. We have found that the endothelial cells in dissociated hearts, isolated from $5 \mathrm{dpf}$ zebrafish embryos,form colonies ona fibronectin substratum; however, these cultures could only be maintained for short periods, possibly because of low seeding-density [173].

These studies suggest that zebrafish embryonic cell culture can be an important model for studying endothelial differentiation and vascular morphogenesis in vitro. In principle, it could be possible to use zebrafish $k d r l: G F P$ embryos for the isolation of endothelial cells using fluorescence activated cell sorting (FACS). The development of these cells into vascular networks in response to various signals could then be readily tracked in live cultures without the need to fix and stain them. Furthermore, tissues and organ explants from zebrafish embryos can be a promising model for sprouting angiogenesis, as we have shown using liver and heart explants from 5 dpf embryos [173].

In summary, the zebrafish allows easy access to large numbers of primary cells, and vascular development in cultures derived from these cells occurs in a complex environment of other cell types. In contrast, it is difficult to access primary cells and tissues in mammalian models, and the vascular culture using endothelial cell lines such as HUVECs does not reflect the complex process in vivo.

\subsection{Disadvantages of zebrafish in vitro model}

Zebrafish embryonic cell cultures usually combine cells or tissues from a large number of individuals due to the small size of embryos [216]. As a result, the cell population obtained is genetically heterogeneous, and may not be ideal for gene expression analysis [216]. Despite the simplicity of the required culture conditions (i.e. low incubation temperature and no requirement for a $\mathrm{CO}_{2}$-enriched atmosphere), studies have shown that zebrafish primary embryonic cells require a complex medium containing FGF and fish embryo extract for their 
growth [213]. The lower incubation temperature for zebrafish cells may not be ideal for human cells if a co-culture has to be established.

The zebrafish embryonic cells usually have to be cultured on a feeder layer of growtharrested cells to maintain their pluripotency [211]. The development of vascular network in primary zebrafish embryonic cells and tissues in the presence of other supporting cell types may be considered as an advantage as it closely mimic the in vivo situation. However, this provides less control over the in vitro vascular development compared to endothelial cell lines. Furthermore, because the zebrafish is a relatively new research model, the differentiation and culture conditions for its cells still needs to be optimised.

\section{Organoids: un-vascularized organotypic cultures}

A remarkable capacity for self-organization in vitro is shown by stem cells (embryonic or adult pluripotent stem cells) and primary tissues (organ explants or dissociated cells). This capacity allows them to develop into 'organoids' - 3D cell masseswith organ-like properties[224]. In an organoid, multiple organ-specific cell types are arranged together, recapitulating some properties (structural and functional) of an organ [225]. The ability to control the differentiation in pluripotent stem cells makes them a model of choice for organoid cultures[226]. Using these cells, organoids of a number of organs including brain, retina, stomach, intestine, lungs, liver and pancreas, have been developed (reviewed in Ref. [12]).The organoid culture not only allowsthe study of developmental processes, it also represents an emerging model system to study diseases, to screen toxicants, and to develop personalized and regenerative medicine[12, 226].

These and other studies suggest organoids might be a good starting point in the effort to develop more complex organ cultures. However, certain limitations of organoid cultures need to be overcome. First, because the cells in an organoid show self-organization, the degree of experiment control over organoid organization is limited; this means thatindividual organoids within the same culture may show cellular heterogeneity[227]. This affects the reproducibility of the results [227].Second, some tissues, such as neural tube and brain,are not easy to establish in 3D culture, although successes are increasingly being 
reported [228]. Finally, the simultaneous effect of growth factors and extracellular matrix in these cultures may inhibit some pathways required for organogenesis [229].

The major issue with organoids, as with other tissue engineering approaches, is the lack of vascularization. This necessarily means that organoids are diffusion-limited and cannot fully develop into mature organs in vitro[228]. One study demonstrated the development of 3D neural organoid constructs with a vascular network inside, by co-culturing neural progenitor cells, endothelial cells, MSCs and macrophage precursors [230]. A similar neurovascular spheroid model has been developed using primary cortical tissue cells isolated from 1-3 days postnatal mice and rats [231]. In another study theintestinal organoids developed from human ESCs were implanted in mice under the kidney capsule[232]. These organoids further expanded, maturated and demonstrated intestinal morphology and function after vascularization by the host vasculature[232].

Taking it a step further, the use of decellularized whole organs as scaffolds for culturing bioartificial organs are now gaining interest. In this technique the cell population of an organ is removed by perfusion with detergents or by mechanical means, while retaining the original three dimensional shape of the extracellular matrix[233]. These organ scaffolds are then repopulated with stem cells, endothelial cells or a mixture of specific cell types (depending on which organ was used) to generate an organ culture [233]. Using this strategy Ottet al. have developed a heart construct using decellularized rat heart seeded with cardiac or endothelial cells [234]. The recellularized construct retained the physiological structure of the heart and showed contractions, pump function and response to drugs [234].Similarly, decellularized rat intestine becomes vascularized when human endothelial cells are seeded into its empty vascular channels[235].

\section{Beyond organoids: microfluidics and the development of a functional vascular network}

In this final section we want to look at some future prospects in the field of in vitro vascular networks. These networks will always remain of limited value unless they support a functional blood flow. In a living animal, this flow is powered by the heart. But how can blood flow be initiated and maintained in a culture system? One obvious answer is to use 
microfluidic technologies to pump blood or some nutrient liquid through the vascular network.

Microfluidic systems give control over the biophysical and biochemical microenvironment of cells, allowing the analysis of complex interactions between different cell types and the respective signalling molecules [236].Microfluidic devices(chips) are made from various material (including glass and poly dimethyl-siloxane), using microfabrication techniques. They contain hollow channels that can be filled with ECM components and medium [13]. The devices can simply be connected to a medium reservoir to generate a passive flow through the channels; or to a pump for more constant flow rate (Table 5).Using unique combinations of materials (with different structural and mechanical properties), microfabrication techniques, ECM components, growth factors, cell types and flow rates, a controlled environment can be created to promote vascular development [236].

These properties of microfluidic systemsmight, in the future, be adaptable to the vascularisation of organoids in vitro. This, in turn, could allow more advanced development, by providing chemical cues and nutrient/waste exchange through a perfusable vascular bed. Connecting an organoid culture to a microfluidic vascular bed would also allow the required changes in gene expression in response to the shear stress generated by the flow of medium.

Microfluidicscould also make it possible to manipulate the course of organogenesis in organoid cultures. For example, the flow rate could be increased with time to fulfil the increasing nutrient requirements of the growing tissue. Designing a microfluidic device with multiple channels connected to different parts of the culture chamber, could also allow the delivery of a specific growth factor to aspecific region of the developing organ. Furthermore, a microfluidic vascularized organ culture would make it possible to visualize the core of optically dense tissues by introducing staining solutions through the vasculature.

\subsection{Examples of microfluidic vascular culture systems}

The microfluidic systems designed for culturing vascular networks are summarized in Table 5 and Figure 4. In one example of vascular culture in a microfluidic system, HUVECs and human lung fibroblasts were co-cultured in a perfused 3D fibrin gel [237]. Thenetworks that developed allowed the transport of nutrients, molecules and cells, and also showed 
physiological responses to flow-induced shear stress [237]. The flow rate in this experiment was $5 \mu \mathrm{L} / \mathrm{min}$, which generated a shear stress of $0.31-7.22 \mathrm{dyne} / \mathrm{cm}^{2}$. This value is close to the physiological level of shear stress ( 1 to $10 \mathrm{dyne} / \mathrm{cm}^{2}$ ) [237]. It should be noted that the shear stress generated by a particular flow rate depends on the dimensions of the microfluidic channels. In the same microfluidic device the authors showed that the presence of flow (regardless of flow direction) facilitates vasculogenesis by HUVECs, and that angiogenic sprouting occurs only in the direction opposite to the flow direction[238]. Similarly, angiogenic sprouting in 3D collagen type-I gel from HUVEC cultures in a microfluidic device showed morphological features resembling in vivo angiogenesis [239].

Table 5. Microfluidic devices for the culture of vascular networks.

\begin{tabular}{|c|c|c|c|c|c|c|c|}
\hline $\begin{array}{l}\text { Device } \\
\text { design* }\end{array}$ & $\begin{array}{l}\text { Cell types } \\
\text { used }\end{array}$ & $\begin{array}{l}\text { Flow } \\
\text { conditio } \\
\mathrm{n}\end{array}$ & $\begin{array}{l}\text { 3D } \\
\text { matrix }\end{array}$ & $\begin{array}{l}\text { Medium } \\
\text { additive } \\
\mathrm{S}\end{array}$ & Main outcomes & $\begin{array}{l}\text { Possible } \\
\text { applications }\end{array}$ & Ref. \\
\hline & HMVEC & Passive & $\begin{array}{l}\text { Col-1, } \\
\text { PDL }\end{array}$ & $\begin{array}{l}\text { EGM- } \\
2 M V \\
\text { VEGF }\end{array}$ & $\begin{array}{l}\text { Endothelial tube-like } \\
\text { structures regressed in } \\
\text { PDL treated channel after } \\
2-3 \text { days. }\end{array}$ & $\begin{array}{l}\text { Tissue } \\
\text { engineering }\end{array}$ & [93] \\
\hline & $\begin{array}{l}\text { HUVEC } \\
\text { NHLF } \\
\text { HPP }\end{array}$ & $\begin{array}{l}\text { Active: } \\
5 \\
\mu \mathrm{L} / \min \end{array}$ & Fibrin & EGM-2 & $\begin{array}{l}\text { Perfusable 3D vascular } \\
\text { network. }\end{array}$ & $\begin{array}{l}\text { Tissue } \\
\text { engineering, } \\
\text { drug screening }\end{array}$ & [237] \\
\hline & $\begin{array}{l}\text { HUVEC } \\
\text { NHLF }\end{array}$ & Passive & Fibrin & EGM-2 & $\begin{array}{l}\text { Flow stimulated } \\
\text { angiogenic sprouting } \\
\text { opposite to direction of } \\
\text { flow. }\end{array}$ & $\begin{array}{l}\text { Cancer } \\
\text { research }\end{array}$ & [238] \\
\hline & HUVEC & Passive & Col-1 & EGM-2 & $\begin{array}{l}\text { Directional neovessel } \\
\text { growth in response to } \\
\text { angiogenic signals. }\end{array}$ & $\begin{array}{l}\text { Drug } \\
\text { screening }\end{array}$ & [239] \\
\hline & $\begin{array}{l}\text { HUVEC } \\
\text { HBMSC } \\
\text { OB }\end{array}$ & $\begin{array}{l}\text { Active: } \\
2 \\
\mu \mathrm{L} / \min \end{array}$ & Fibrin & $\begin{array}{l}\text { EGM- } \\
2 M V \\
\text { VEGF, } \\
\text { Ang1 }\end{array}$ & $\begin{array}{l}\text { Tumorcellextravasation } \\
\text { into the surrounding } \\
\text { bone-mimicking matrix. }\end{array}$ & $\begin{array}{l}\text { Cancer } \\
\text { research, drug } \\
\text { screening }\end{array}$ & [240] \\
\hline & $\begin{array}{l}\text { HUVEC } \\
\text { NHLF }\end{array}$ & Passive & Fibrin & EGM-2 & $\begin{array}{l}\text { Easy quantification of } \\
\text { tumor cell extravasation. }\end{array}$ & $\begin{array}{l}\text { Cancer } \\
\text { research }\end{array}$ & [241] \\
\hline & HMVEC & $\begin{array}{l}\text { Active: } \\
1-2 \\
\mu \mathrm{L} / \min \end{array}$ & Col-1 & $\begin{array}{l}\text { EGM- } \\
2 \mathrm{MV} \\
\text { VEGF }\end{array}$ & $\begin{array}{l}\text { Metalloproteinases } \\
\text { modulated the length and } \\
\text { diameter of vessels in 3D } \\
\text { ECM. }\end{array}$ & $\begin{array}{l}\text { Developmenta } \\
\text { I studies, } \\
\text { tissue } \\
\text { engineering }\end{array}$ & [242] \\
\hline & $\begin{array}{l}\text { ECFC-EC } \\
\text { NHLF } \\
\text { CC }\end{array}$ & Passive & $\begin{array}{l}\text { Fibrin, } \\
\text { laminin }\end{array}$ & EGM-2 & $\begin{array}{l}\text { A vascularized tumor } \\
\text { model responding to } \\
\text { chemical stimuli. }\end{array}$ & $\begin{array}{l}\text { Cancer } \\
\text { research }\end{array}$ & [243] \\
\hline & $\begin{array}{l}\text { iPSC-EC } \\
\text { NHLF }\end{array}$ & Passive & Fibrin & VVM & $\begin{array}{l}\text { iPSC-ECs formed inter- } \\
\text { connected capillaries with } \\
\text { lumina }\end{array}$ & $\begin{array}{l}\text { Disease } \\
\text { modelling, } \\
\text { drug screening }\end{array}$ & [244] \\
\hline & iPSC-EC & Passive & PEG & $\begin{array}{l}\text { VVM, } \\
\text { VEGF }\end{array}$ & $\begin{array}{l}\text { iPSC-ECs self-organized } \\
\text { into tubular networks, } \\
\text { VEGF enhanced network } \\
\text { formation. }\end{array}$ & $\begin{array}{l}\text { Tissue } \\
\text { engineering, } \\
\text { drug screening }\end{array}$ & [245] \\
\hline
\end{tabular}




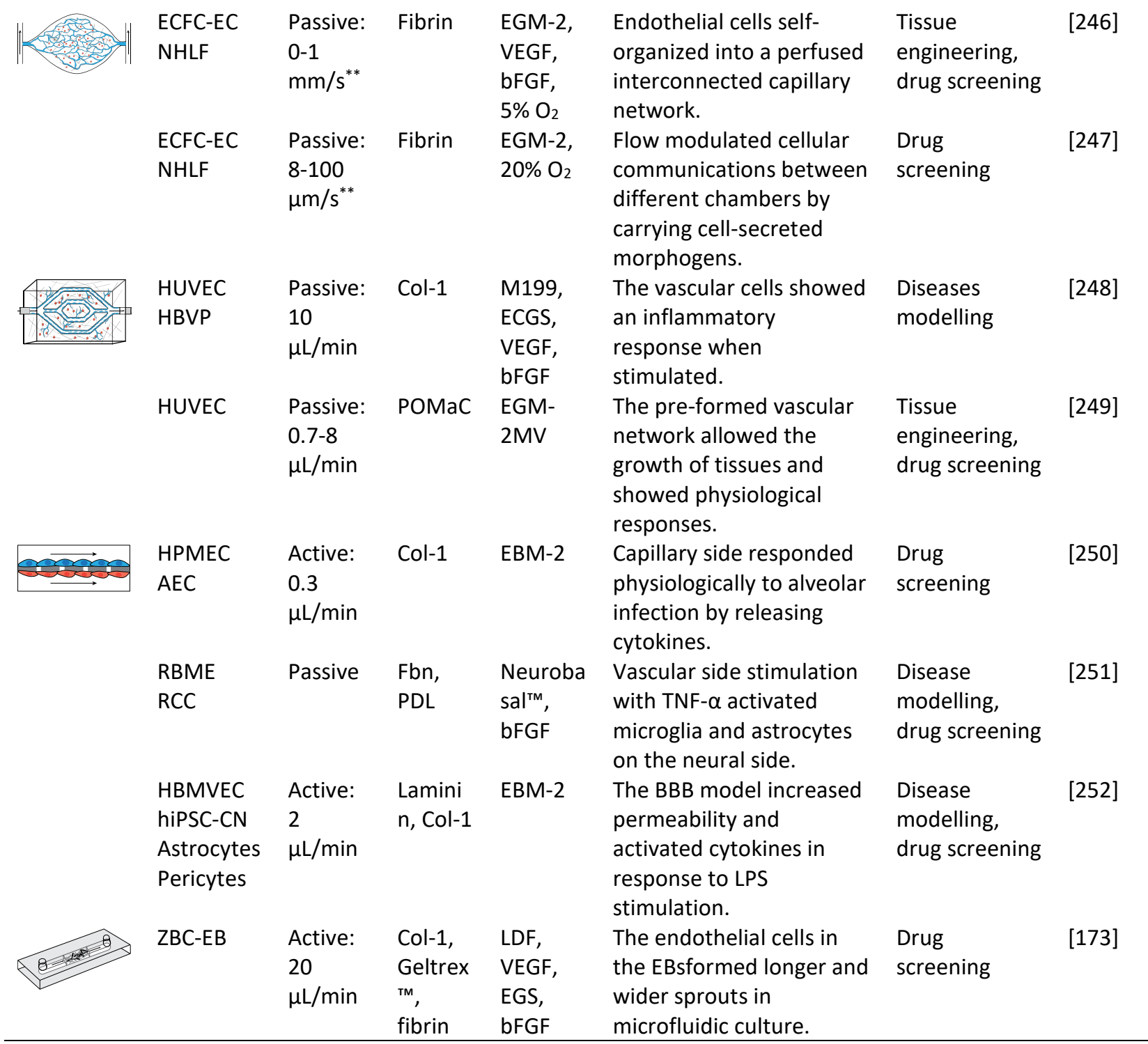

Abbreviations and symbols:Active, flow is generated by a pump with constant flow rate; PDL, poly-D-lysine; AEC, alveolar epithelial cells; Ang-1, angiopoietin-1; bFGF, basic fibroblast growth factor; CC, cancer cells (colorectal, breast or melanoma cell line); Col-1, collagen type-I; EBM, endothelial basal medium; ECFC-EC, human endothelial colony forming cell-derived endothelial cells;ECGS, endothelial cell growth supplement;EGM, endothelial growth medium; EGM-2MV, endothelial growth medium microvascular;Fbn, fibronectin;HBMSC, human bone marrow-derived mesenchymal stem cells; HBMVEC, human brain-derived microvascular endothelial cells;HBVP, human brain vascular pericytes; hiPSC-CN, humaninduced pluripotent stem cell-derived cortical neurons; HMVEC, human dermal microvascular endothelial cells; HPMEC, human pulmonary microvascular endothelial cells; HPP, human placental pericytes; HUVEC, human umbilical vein endothelial cells; iPSC-EC, human induced pluripotent stem cells-derived endothelial cells;M199, medium 199 (Lonza); NHLF, human normal lung fibroblasts; OB, osteoblasts; Passive, the flow is generated by hydrostatic pressure of the medium in a reservoir; PEG, polyethylene glycol hydrogel;POMaC, poly(octamethylene maleate (anhydride) citrate); RBME, rat brain microvascular endothelial cells; RCC, E-18 rat cortical cells; TNF- $\alpha$, tumor necrosis factor alpha; VEGF, vascular endothelial growth factor; VVM, VascuLife ${ }^{\circledR}$ VEGF medium; ZBC-EB, zebrafish blastocyst cell-derived embryoid bodies; *, see Figure 4 for further description of device design; **, flow velocity calculated by tracking the movement of fluorescent dextran particles through the network.

These studies employed a commonly-used microfluidic design containing a middle channel filled with ECM, and interconnected with two side channels which conduct the medium flow (Figure 4A).In this device the vascular network is connected to the media channels through 
the lumen openings[241]. This allows the vascular network to be perfused by chemical compounds or cells. The device allows rapid quantification of changes in vascular networks in response to test compounds[241].Using the same design, Jeon et al. have shown the extravasation of cancer cells, introduced through the perfused vascular network, into the surrounding bone-mimicking matrix [240]. In a similar device, human colorectal or breast cancer cells co-cultured with endothelial cellsin 3D ECM in the middle channel have been shown to develop into vascularizedtumor aggregates[243]. These tumor-like structures showed reduced growth, and sometimes even regression occurred,in response to standard vascular targeting therapies infused via the microvessels[243].

Based on a similar principle, Moya et al.[246] designed a chambered central channel with each chamber connected to the two microfluidic channels on either side through a $30 \mu \mathrm{m}$ pore (Figure 4B). In that study the authors demonstrated that the endothelial cells, cocultured with fibroblasts in 3D fibrin matrix in the central chambers, self-assembled into an interconnected capillary network, that anastomosed on each side to the channels (Table 5). This device allows the culture of multiple, vascularized microtissues which were nearly identical between the different chambers[253]. The geometry of microfluidic channels and media reservoirs in this device, allow better control over the flow distribution in each chamber to generate near physiological shear stress [253]. Furthermore, these channels also allowed the transport of chemical signals from one culture chamber to the other [247].Using a modified version of this device, with an extended central chamber connected by multiple pores to the side channels, Hsu et al.have shown that interstitial flow and hypoxia can independently stimulate vasculogenesis [254].

Another device (Figure 4C) mimics the alveolar capillary interface by allowing the culture of human pulmonary microvascular endothelial cells on one side, and alveolar epithelial cells on the other, of a porous membrane inside a microfluidic channel[250]. This device allows the transport of chemical signals from one compartment to the other on stimulation [250]. This technique can be applied to develop other organ models (such as intestine, kidney, liver and blood-brain barrier), by culturing the corresponding cells in the device [255].An alternative approach is the pre-moulded hollow network (Figure 4D) in a 3D collagen type-I matrixwith embedded supporting cells (in this case, human brain vascular pericytes)[248].In 
that study, the HUVECswere seeded into the cavities of cast, which first formed a lining to the cast channels, and then formed vascular sprouts into the surrounding matrix [248].

A

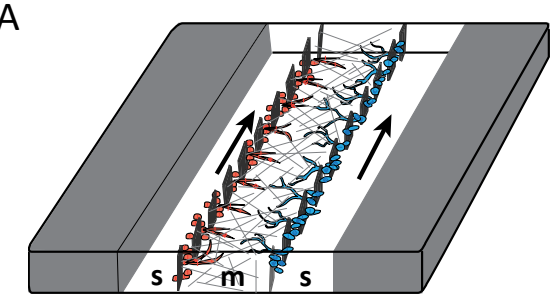

C

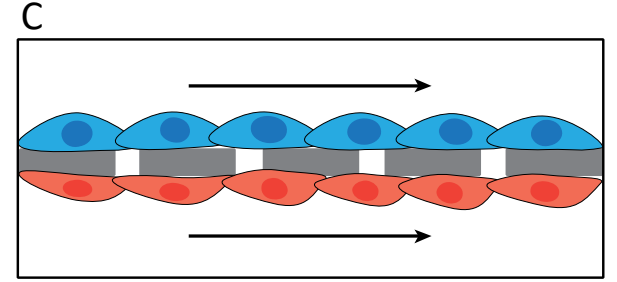

B

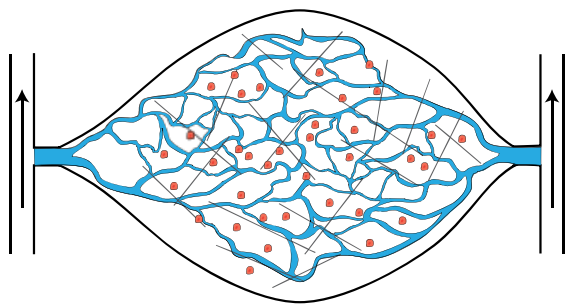

$\mathrm{D}$

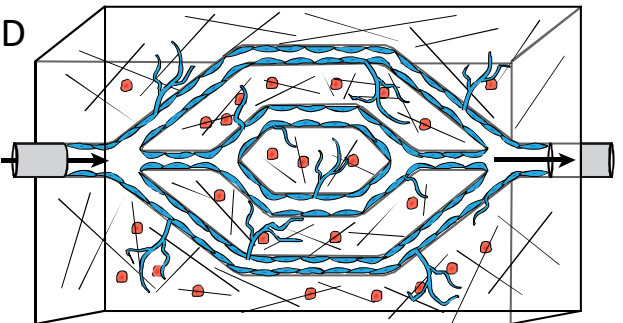

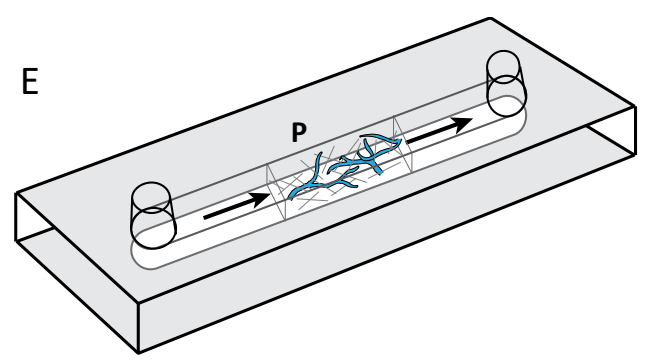

Figure 4. Microfluidic devices commonly used for culturing vascular-like networks. (A) Three channel microfluidic device $[238,240]$. The middle channel $(m)$ is filled with extracellular matrix with embedded cells. The two side channels (s) conduct the medium flow (arrows). (B) Device with a central culture chamber connected to two channels on either side [246]. Endothelial cells embedded in 3D matrix in the central chamber selforganize into a network, allowing medium perfusion from one channel to the other. (C) Microfluidic device mimicking capillary-tissue interface with endothelial cells on one side and epithelial cells on other side of a porous membrane [250]. The medium flow (arrows) can be established on the endothelial side only, or on both sides. (D) In this device, endothelial cells line the built-in channels cut into a hydrogel with embedded supporting cells $[248,249]$. (E) A microfluidic channel slide with a 3D matrix plug $(P)$ in the middle of the channel [173]. The medium flows on either side of the plug (a small amount may penetrate the gel by diffusion). Note that (B and D) comes closest to a growing vascular bed connected to the microfluidic system. Arrows showing the direction of the medium flow. For further discussion of microfluidic devices in the field of vascular culture, see Refs. $[13,99,256]$.

In a similar device, a perfused vasculature has been developed by seeding HUVECs inside moulded channels in a synthetic scaffold [249]. The network thus formed was able to vascularize cardiac and hepatic tissues cultured on the outside of the scaffold. The material used for the scaffold in that study waspoly(octamethylene maleate (anhydride) citrate) (POMaC;a biodegrade-able and biocompatible scaffold) [249]. In that setup, the micro pores 
incorporated into the scaffold allowed the uptake of nutrients, chemical compounds and cells from the vessels, and the release of metabolites into the vessels by the surrounding tissue [249].By increasing the flow rate (from 0.7 to $8.0 \mu \mathrm{L} / \mathrm{min}$ ) across the lifespan of the culture, this device allowed the growth of tissues of up to $2 \mathrm{~mm}$ thickness.

In most of the cases discussed above, endothelial cell lines are used to culturevascular networksin a microfluidic system. The stem cells and explant cultures have been very little used in such studies. We have shown that zebrafish EBs embedded in a 3D matrix(mixed collagen type-I, Geltrex ${ }^{\mathrm{TM}}$ and fibrin gel components),formed longer and wider vascular sprouts when cultured in a microfluidic channel (Figure $4 \mathrm{E}$ ) compared to the conventional (static) 96-well plates[173].

\subsection{Technical challenges for the future}

As we have discussed above, scientists are getting closer to reaching the goal of a functional vascular network perfused by microfluidics in vitro. However, there are some severe technical challengesto be overcome. Presumably, some kind of synthetic interface or connector will be needed to connect the living vessels with microfluidic system. Another major challenge will be to maintain an increasing blood flow as the tissue explant, attached to the vascular network, grows in size. Thus, the growing tissue will require vessels of increasing diameter, and this in turn will require an expanding connection to the microfluidic system. Solutions to these problems will require intensive research.

\section{Conclusions}

In summary, the techniques developed for in vitrovascular network formation in mammals are producing rapid advances in our understanding. They can also be applied to zebrafish cells and tissues. For its benefits such as easy access to primary embryonic cells, availability of transgenic lines to visualize endothelial cells andconserved molecular pathways, the zebrafish can be a significant first-step model for studying in vitro vascular development. Lack of a functional vascular system is currently the major limitation to take the organoid technology a step further to develop whole organ culture.In recent years, microfluidic technology have shown great advances in developing in vitroperfused vascular networks. Ultimately, the future of tissue culture and organ culture will be greatly extended if a 
functional vascular network can be developed, that have the ability to transport the required factors for the growth and to remove metabolites of the tissues in vitro. The major challenges in establishing such a system, that the future studies must overcome, would be to recapitulate the key features of vascular system such as barrier function and vasoactivity, besides weather or not the vascular network is perfusable. Further research will be required to develop a microfluidic system in which there is a remodelling of the vascular-to-hardware connection, as would be essential in order to meet the increasing demands of the growing tissue.

\section{Acknowledgements}

This work was supported by the Smart Mix programme of the Netherlands Ministry of Economic Affairs and the Netherlands Scientific Research Council (NWO)[grant number SSM06010]; and the Generade programme of the Centre of Expertise Genomics in Leiden, The Netherlands[grant number 2016_004].

\section{References}

[1] J.R. Levick, The microcirculation and solute exchange, An Introduction to cardiovascular physiology, Taylor \& Francis2010, pp. 166-187.

[2] R.Y. Kannan, H.J. Salacinski, K. Sales, P. Butler, A.M. Seifalian, The roles of tissue engineering and vascularisation in the development of micro-vascular networks: a review, Biomaterials 26(14) (2005) 1857-75.

[3] R.K. Jain, P. Au, J. Tam, D.G. Duda, D. Fukumura, Engineering vascularized tissue, Nat. Biotechnol. 23(7) (2005) 821-3.

[4] V. Marx, Tissue engineering: organs from the lab, Nature 522(7556) (2015) 373-7.

[5] J.J. Kim, L. Hou, N.F. Huang, Vascularization of three-dimensional engineered tissues for regenerative medicine applications, Acta Biomater. 41 (2016) 17-26.

[6] H. Bae, A.S. Puranik, R. Gauvin, F. Edalat, B. Carrillo-Conde, N.A. Peppas, A. Khademhosseini, Building vascular networks, Sci. Transl. Med. 4(160) (2012) 160ps23.

[7] F. Groeber, L. Engelhardt, J. Lange, S. Kurdyn, F.F. Schmid, C. Rucker, S. Mielke, H. Walles, J. Hansmann, A first vascularized skin equivalent for as an alternative to animal experimentation, ALTEX 33(4) (2016) 415-422.

[8] M. Rezvani, A.A. Grimm, H. Willenbring, Assessing the therapeutic potential of lab-made hepatocytes, Hepatology 64(1) (2016) 287-94.

[9] D.K. Nayak, P.B. Saravanan, S. Bansal, B. Naziruddin, T. Mohanakumar, Autologous and allogenous antibodies in lung and islet cell transplantation, Front. Immunol. 7 (2016) 650.

[10] M. Lovett, K. Lee, A. Edwards, D.L. Kaplan, Vascularization strategies for tissue engineering, Tissue Eng. Part B Rev. 15(3) (2009) 353-70. 
[11] L.B. Weiswald, D. Bellet, V. Dangles-Marie, Spherical cancer models in tumor biology, Neoplasia 17(1) (2015) 1-15.

[12] H. Clevers, Modeling development and disease with organoids, Cell 165(7) (2016) 158697.

[13] M. Ibrahim, M.K. Richardson, Microfluidic devices for cell, tissue and embryo culture, Rec. Pat. Regen. Med. 3(3) (2013) 249-263.

[14] D. Rosenfeld, S. Landau, Y. Shandalov, N. Raindel, A. Freiman, E. Shor, Y. Blinder, H.H. Vandenburgh, D.J. Mooney, S. Levenberg, Morphogenesis of 3D vascular networks is regulated by tensile forces, Proc. Natl. Acad. Sci. U. S. A. 113(12) (2016) 3215-20.

[15] K. Shan, C.P. Li, C. Liu, X. Liu, B. Yan, RNCR3: a regulator of diabetes mellitus-related retinal microvascular dysfunction, Biochem. Biophys. Res. Commun. 482(4) (2017) 777-783.

[16] L.C. Roudsari, J.L. West, Studying the influence of angiogenesis in in vitro cancer model systems, Adv. Drug Deliv. Rev. 97 (2016) 250-9.

[17] M.S. Azimi, M. Lacey, D. Mondal, W.L. Murfee, An ex vivo tissue culture model for antiangiogenic drug testing, Methods Mol. Biol. 1464 (2016) 85-95.

[18] C. Therapontos, L. Erskine, E.R. Gardner, W.D. Figg, N. Vargesson, Thalidomide induces limb defects by preventing angiogenic outgrowth during early limb formation, Proc. Natl. Acad. Sci. U. S. A. 106(21) (2009) 8573-8.

[19] T. Zou, J. Fan, A. Fartash, H. Liu, Y. Fan, Cell-based strategies for vascular regeneration, J. Biomed. Mater. Res. A 104(5) (2016) 1297-314.

[20] I.M. Antonopoulos, K.G. Yamacake, L.M. Oliveira, A.C. Piovesan, H. Kanashiro, W.C. Nahas, Revascularization of living-donor kidney transplant with multiple arteries: long-term outcomes using the inferior epigastric artery, Urology 84(4) (2014) 955-9.

[21] T. Takebe, R.R. Zhang, H. Koike, M. Kimura, E. Yoshizawa, M. Enomura, N. Koike, K. Sekine, H. Taniguchi, Generation of a vascularized and functional human liver from an iPSCderived organ bud transplant, Nat. Protoc. 9(2) (2014) 396-409.

[22] R. Rugh, Intra-embryonic transplantations, Experimental embryology: techniques and procedures, Burgess Pub. Co.1962, pp. 443-448.

[23] R.L. Searls, A.A. Smith, Evidence that ectoderm influences the differentiation of muscle in the limb of the embryonic chick, J. Exp. Zool. 220(3) (1982) 343-51.

[24] R. Rugh, The methods of chorio-allantoic grafting, Experimental embryology: techniques and procedures, Burgess Pub. Co.1962, pp. 437-442.

[25] D. Ribatti, The chick embryo chorioallantoic membrane (CAM). A multifaceted experimental model, Mech. Dev. 141 (2016) 70-7.

[26] S. Festing, R. Wilkinson, The ethics of animal research. Talking Point on the use of animals in scientific research, EMBO Rep. 8(6) (2007) 526-30.

[27] I. Arnaoutova, H.K. Kleinman, In vitro angiogenesis: endothelial cell tube formation on gelled basement membrane extract, Nat. Protoc. 5(4) (2010) 628-35.

[28] M.N. Chavez, G. Aedo, F.A. Fierro, M.L. Allende, J.T. Egana, Zebrafish as an emerging model organism to study angiogenesis in development and regeneration, Front. Physiol. 7 (2016) 56.

[29] R. Dahm, R. Geisler, Learning from small fry: the zebrafish as a genetic model organism for aquaculture fish species, Mar. Biotechnol. (NY) 8(4) (2006) 329-45.

[30] U. Strahle, S. Scholz, R. Geisler, P. Greiner, H. Hollert, S. Rastegar, A. Schumacher, I. Selderslaghs, C. Weiss, H. Witters, T. Braunbeck, Zebrafish embryos as an alternative to animal experiments--a commentary on the definition of the onset of protected life stages in animal welfare regulations, Reprod. Toxicol. 33(2) (2012) 128-32. 
[31] K. Howe, M.D. Clark, C.F. Torroja, J. Torrance, C. Berthelot, M. Muffato, J.E. Collins, S. Humphray, K. McLaren, L. Matthews, S. McLaren, et al., The zebrafish reference genome sequence and its relationship to the human genome, Nature 496(7446) (2013) 498-503.

[32] R.N. Wilkinson, F.J. van Eeden, The zebrafish as a model of vascular development and disease, Prog. Mol. Biol. Transl. Sci. 124 (2014) 93-122.

[33] G.J. Lieschke, P.D. Currie, Animal models of human disease: zebrafish swim into view, Nat. Rev. Genet. 8(5) (2007) 353-67.

[34] D. Ribatti, B. Nico, E. Crivellato, The development of the vascular system: a historical overview, Methods Mol. Biol. 1214 (2015) 1-14.

[35] M.K. Richardson, Heterochrony and the phylotypic period, Dev. Biol. 172(2) (1995) 41221.

[36] A. Schmidt, K. Brixius, W. Bloch, Endothelial precursor cell migration during vasculogenesis, Circ. Res. 101(2) (2007) 125-36.

[37] A.V. Gore, K. Monzo, Y.R. Cha, W. Pan, B.M. Weinstein, Vascular development in the zebrafish, Cold Spring Harb. Perspect. Med. 2(5) (2012) a006684.

[38] D. Ribatti, The discovery of endothelial progenitor cells. An historical review, Leuk. Res. 31(4) (2007) 439-44.

[39] W. Risau, Mechanisms of angiogenesis, Nature 386(6626) (1997) 671-4.

[40] R.H. Adams, K. Alitalo, Molecular regulation of angiogenesis and lymphangiogenesis, Nat. Rev. Mol. Cell Biol. 8(6) (2007) 464-78.

[41] P. Lu, K. Takai, V.M. Weaver, Z. Werb, Extracellular matrix degradation and remodeling in development and disease, Cold Spring Harb. Perspect. Biol. 3(12) (2011).

[42] S.J. Mentzer, M.A. Konerding, Intussusceptive angiogenesis: expansion and remodeling of microvascular networks, Angiogenesis 17(3) (2014) 499-509.

[43] K.L. Marcelo, L.C. Goldie, K.K. Hirschi, Regulation of endothelial cell differentiation and specification, Circ. Res. 112(9) (2013) 1272-87.

[44] G.D. Yancopoulos, S. Davis, N.W. Gale, J.S. Rudge, S.J. Wiegand, J. Holash, Vascularspecific growth factors and blood vessel formation, Nature 407(6801) (2000) 242-8.

[45] M. Murakami, M. Simons, Fibroblast growth factor regulation of neovascularization, Curr. Opin. Hematol. 15(3) (2008) 215-20.

[46] C.M. Cox, T.J. Poole, Angioblast differentiation is influenced by the local environment: FGF-2 induces angioblasts and patterns vessel formation in the quail embryo, Dev. Dyn. 218(2) (2000) 371-82.

[47] S. Nicoli, G. De Sena, M. Presta, Fibroblast growth factor 2-induced angiogenesis in zebrafish: the zebrafish yolk membrane (ZFYM) angiogenesis assay, J. Cell. Mol. Med. 13(8B) (2009) 2061-8.

[48] H. Chang, D. Huylebroeck, K. Verschueren, Q. Guo, M.M. Matzuk, A. Zwijsen, Smad5 knockout mice die at mid-gestation due to multiple embryonic and extraembryonic defects, Development 126(8) (1999) 1631-42.

[49] P. Carmeliet, R.K. Jain, Molecular mechanisms and clinical applications of angiogenesis, Nature 473(7347) (2011) 298-307.

[50] N. Ferrara, VEGF-A: a critical regulator of blood vessel growth, Eur. Cytokine Netw. 20(4) (2009) 158-63.

[51] N. Ferrara, H.P. Gerber, J. LeCouter, The biology of VEGF and its receptors, Nat. Med. 9(6) (2003) 669-76.

[52] P. Vempati, A.S. Popel, F. Mac Gabhann, Extracellular regulation of VEGF: isoforms, proteolysis, and vascular patterning, Cytokine Growth Factor Rev. 25(1) (2014) 1-19. 
[53] L.K. Phng, H. Gerhardt, Angiogenesis: a team effort coordinated by notch, Dev. Cell 16(2) (2009) 196-208.

[54] L.F. Newell, S.G. Holtan, Placental growth factor: what hematologists need to know, Blood Rev. (2016).

[55] M. Autiero, J. Waltenberger, D. Communi, A. Kranz, L. Moons, D. Lambrechts, J. Kroll, S. Plaisance, M. De Mol, F. Bono, S. Kliche, et al., Role of PIGF in the intra- and intermolecular cross talk between the VEGF receptors Flt1 and Flk1, Nat. Med. 9(7) (2003) 936-43.

[56] T. Schmidt, P. Carmeliet, Angiogenesis: a target in solid tumors, also in leukemia?, Hematology Am. Soc. Hematol. Educ. Program 2011 (2011) 1-8.

[57] Y.Q. Wang, A. Sizeland, X.F. Wang, D. Sassoon, Restricted expression of type-II TGF beta receptor in murine embryonic development suggests a central role in tissue modeling and CNS patterning, Mech. Dev. 52(2-3) (1995) 275-89.

[58] E. Pardali, M.J. Goumans, P. ten Dijke, Signaling by members of the TGF-beta family in vascular morphogenesis and disease, Trends Cell Biol. 20(9) (2010) 556-67.

[59] C. He, X. Chen, Transcription regulation of the vegf gene by the BMP/Smad pathway in the angioblast of zebrafish embryos, Biochem. Biophys. Res. Commun. 329(1) (2005) 324-30. [60] L.H. Parker, M. Schmidt, S.W. Jin, A.M. Gray, D. Beis, T. Pham, G. Frantz, S. Palmieri, K. Hillan, D.Y. Stainier, F.J. De Sauvage, et al., The endothelial-cell-derived secreted factor Egfl7 regulates vascular tube formation, Nature 428(6984) (2004) 754-8.

[61] D. Vestweber, VE-cadherin: the major endothelial adhesion molecule controlling cellular junctions and blood vessel formation, Arterioscler. Thromb. Vasc. Biol. 28(2) (2008) 223-32.

[62] M. Hellstrom, L.K. Phng, J.J. Hofmann, E. Wallgard, L. Coultas, P. Lindblom, J. Alva, A.K. Nilsson, L. Karlsson, N. Gaiano, K. Yoon, et al., Dll4 signalling through Notch1 regulates formation of tip cells during angiogenesis, Nature 445(7129) (2007) 776-80.

[63] G. Zadeh, K. Koushan, L. Pillo, P. Shannon, A. Guha, Role of Ang1 and its interaction with VEGF-A in astrocytomas, J. Neuropathol. Exp. Neurol. 63(9) (2004) 978-89.

[64] J. Kim, Q. Wu, Y. Zhang, K.M. Wiens, Y. Huang, N. Rubin, H. Shimada, R.I. Handin, M.Y. Chao, T.L. Tuan, V.A. Starnes, et al., PDGF signaling is required for epicardial function and blood vessel formation in regenerating zebrafish hearts, Proc. Natl. Acad. Sci. U. S. A. 107(40) (2010) 17206-10.

[65] H.L. Nguyen, Y.J. Lee, J. Shin, E. Lee, S.O. Park, J.H. McCarty, S.P. Oh, TGF-beta signaling in endothelial cells, but not neuroepithelial cells, is essential for cerebral vascular development, Lab Invest. 91(11) (2011) 1554-63.

[66] C. Park, T.M. Kim, A.B. Malik, Transcriptional regulation of endothelial cell and vascular development, Circ. Res. 112(10) (2013) 1380-400.

[67] B.L. Krock, N. Skuli, M.C. Simon, Hypoxia-induced angiogenesis: good and evil, Genes Cancer 2(12) (2011) 1117-33.

[68] A. Birbrair, T. Zhang, Z.M. Wang, M.L. Messi, A. Mintz, O. Delbono, Pericytes at the intersection between tissue regeneration and pathology, Clin. Sci. (Lond) 128(2) (2015) 8193.

[69] G.R. Campbell, J.H. Campbell, Development of the vessel wall: overview, in: R.P. Mecham (Ed.), The Vascular Smooth Muscle Cell, Academic Press, San Diego, 1995, pp. 1-15.

[70] A. Armulik, G. Genove, C. Betsholtz, Pericytes: developmental, physiological, and pathological perspectives, problems, and promises, Dev. Cell 21(2) (2011) 193-215.

[71] M.D. Sweeney, S. Ayyadurai, B.V. Zlokovic, Pericytes of the neurovascular unit: key functions and signaling pathways, Nat. Neurosci. 19(6) (2016) 771-83. 
[72] T. Schmidt, P. Carmeliet, Blood-vessel formation: bridges that guide and unite, Nature 465(7299) (2010) 697-9.

[73] U.B. Eyo, M.E. Dailey, Microglia: key elements in neural development, plasticity, and pathology, J. Neuroimmune Pharmacol. 8(3) (2013) 494-509.

[74] T.H. Adair, J.P. Montani, Chapter 1. Overview of angiogenesis, Angiogenesis, San Rafael (CA), 2010.

[75] J.E. Italiano, J.L. Richardson, S. Patel-Hett, E. Battinelli, A. Zaslavsky, S. Short, S. Ryeom, J. Folkman, G.L. Klement, Angiogenesis is regulated by a novel mechanism: pro- and antiangiogenic proteins are organized into separate platelet alpha granules and differentially released, Blood 111(3) (2008) 1227-1233.

[76] M. Chatterjee, Z. Huang, W. Zhang, L. Jiang, K. Hultenby, L. Zhu, H. Hu, G.P. Nilsson, N. $\mathrm{Li}$, Distinct platelet packaging, release, and surface expression of proangiogenic and antiangiogenic factors on different platelet stimuli, Blood 117(14) (2011) 3907-11.

[77] J. Rehman, D. Traktuev, J. Li, S. Merfeld-Clauss, C.J. Temm-Grove, J.E. Bovenkerk, C.L. Pell, B.H. Johnstone, R.V. Considine, K.L. March, Secretion of angiogenic and antiapoptotic factors by human adipose stromal cells, Circulation 109(10) (2004) 1292-8.

[78] J.A. Eble, S. Niland, The extracellular matrix of blood vessels, Curr. Pharm. Des. 15(12) (2009) 1385-400.

[79] F. Gattazzo, A. Urciuolo, P. Bonaldo, Extracellular matrix: a dynamic microenvironment for stem cell niche, Biochim. Biophys. Acta 1840(8) (2014) 2506-19.

[80] K.R. Legate, S.A. Wickstrom, R. Fassler, Genetic and cell biological analysis of integrin outside-in signaling, Genes Dev. 23(4) (2009) 397-418.

[81] A. Mammoto, T. Mammoto, D.E. Ingber, Mechanosensitive mechanisms in transcriptional regulation, J. Cell Sci. 125(Pt 13) (2012) 3061-73.

[82] P.D. Yurchenco, Basement membranes: cell scaffoldings and signaling platforms, Cold Spring Harb. Perspect. Biol. 3(2) (2011).

[83] G.E. Davis, D.R. Senger, Endothelial extracellular matrix: biosynthesis, remodeling, and functions during vascular morphogenesis and neovessel stabilization, Circ. Res. 97(11) (2005) 1093-107.

[84] J.E. Wagenseil, R.P. Mecham, Vascular extracellular matrix and arterial mechanics, Physiol. Rev. 89(3) (2009) 957-89.

[85] J.E. Schwarzbauer, D.W. DeSimone, Fibronectins, Their Fibrillogenesis, and In Vivo Functions, Cold Spring Harb. Perspect. Biol. 3(7) (2011).

[86] W. Bergmeier, R.O. Hynes, Extracellular matrix proteins in hemostasis and thrombosis, Cold Spring Harb Perspect Biol 4(2) (2012).

[87] P. Allen, J. Melero-Martin, J. Bischoff, Type I collagen, fibrin and PuraMatrix matrices provide permissive environments for human endothelial and mesenchymal progenitor cells to form neovascular networks, J. Tissue Eng. Regen. Med. 5(4) (2011) e74-86.

[88] D.E. Glaser, W.S. Turner, N. Madfis, L. Wong, J. Zamora, N. White, S. Reyes, A.B. Burns, A. Gopinathan, K.E. McCloskey, Multifactorial optimizations for directing endothelial fate from stem cells, PLoS One 11(12) (2016) e0166663.

[89] A. Hielscher, K. Ellis, C. Qiu, J. Porterfield, S. Gerecht, Fibronectin Deposition Participates in Extracellular Matrix Assembly and Vascular Morphogenesis, PLoS One 11(1) (2016) e0147600.

[90] K. Stamati, J.V. Priestley, V. Mudera, U. Cheema, Laminin promotes vascular network formation in 3D in vitro collagen scaffolds by regulating VEGF uptake, Exp. Cell Res. 327(1) (2014) 68-77. 
[91] G. Benton, I. Arnaoutova, J. George, H.K. Kleinman, J. Koblinski, Matrigel: from discovery and ECM mimicry to assays and models for cancer research, Adv. Drug Deliv. Rev. 79-80 (2014) 3-18.

[92] M.P. Lutolf, J.A. Hubbell, Synthetic biomaterials as instructive extracellular microenvironments for morphogenesis in tissue engineering, Nat. Biotechnol. 23(1) (2005) 47-55.

[93] S. Chung, R. Sudo, I.K. Zervantonakis, T. Rimchala, R.D. Kamm, Surface-treatmentinduced three-dimensional capillary morphogenesis in a microfluidic platform, Adv. Mater. 21(47) (2009) 4863-7.

[94] P.F. Davies, Hemodynamic shear stress and the endothelium in cardiovascular pathophysiology, Nat. Clin. Pract. Cardiovasc. Med. 6(1) (2009) 16-26.

[95] H. Zhang, S.W. Sunnarborg, K.K. McNaughton, T.G. Johns, D.C. Lee, J.E. Faber, Heparinbinding epidermal growth factor-like growth factor signaling in flow-induced arterial remodeling, Circ. Res. 102(10) (2008) 1275-85.

[96] N.A. Rashdan, P.G. Lloyd, Fluid shear stress upregulates placental growth factor in the vessel wall via NADPH oxidase 4, Am. J. Physiol. Heart Circ. Physiol. 309(10) (2015) H1655-66. [97] E.D. Jahnsen, A. Trindade, H.C. Zaun, S. Lehoux, A. Duarte, E.A. Jones, Notch1 is panendothelial at the onset of flow and regulated by flow, PLoS One 10(4) (2015) e0122622.

[98] J.N. Topper, J. Cai, Y. Qiu, K.R. Anderson, Y.Y. Xu, J.D. Deeds, R. Feeley, C.J. Gimeno, E.A. Woolf, O. Tayber, G.G. Mays, et al., Vascular MADs: two novel MAD-related genes selectively inducible by flow in human vascular endothelium, Proc. Natl. Acad. Sci. U. S. A. 94(17) (1997) 9314-9.

[99] A. Hasan, A. Paul, N.E. Vrana, X. Zhao, A. Memic, Y.S. Hwang, M.R. Dokmeci, A. Khademhosseini, Microfluidic techniques for development of 3D vascularized tissue, Biomaterials 35(26) (2014) 7308-25.

[100] X. Sun, W. Altalhi, S.S. Nunes, Vascularization strategies of engineered tissues and their application in cardiac regeneration, Adv. Drug Deliv. Rev. 96 (2016) 183-94.

[101] ATCC, Endothelial cells. <https://www.lgcstandardsatcc.org/Products/Cells\%20and\%20Microorganisms/Human\%20Primary\%20Cells/Cell\%20Ty pe/Endothelial\%20Cells.aspx?geo country=nl>, 2017 (accessed 14 March.2017).

[102] Lonza, Endothelial cells (normal and diseased) \& media. $<$ http://www.lonza.com/products-services/bio-research/primary-cells/human-cells-andmedia/endothelial-cells-and-media.aspx $>2017$ (accessed 14 March.2017).

[103] PromoCell, Human primary cells. <http://www.promocell.com/products/humanprimary-cells/>, 2017 (accessed 14 March.2017).

[104] ThermoFischer, Large vessel endothelial cell culture systems. <https://www.thermofisher.com/nl/en/home/life-science/cell-culture/primary-cell-

culture/large-vessel-endothelial-cell-culture-

systems.html?gclid=CKqn6aGBn9QCFQs GwodthklkQ\&s kwcid=AL!3652!3!177644503670!b !! g! !\%2Bendothelial\%20\%2Bcell\%20\%2Bline\&mkwid=s-

dc pcrid 177644503670 pkw +endothelial\%20+cell\%20+line pmt b slid \&ef id=WO5Hg AAAASAJZQvd:20170602110145:s>, 2017 (accessed 14 March.2017).

[105] Y. Chen, Y. Zhang, Q. Deng, N. Shan, W. Peng, X. Luo, H. Zhang, P.N. Baker, C. Tong, H. Qi, Inhibition of Wnt inhibitory factor 1 under hypoxic condition in human umbilical vein endothelial cells promoted angiogenesis in vitro, Reprod. Sci. 23(10) (2016) 1348-58.

[106] S. Rohringer, P. Hofbauer, K.H. Schneider, A.M. Husa, G. Feichtinger, A. PeterbauerScherb, H. Redl, W. Holnthoner, Mechanisms of vasculogenesis in 3D fibrin matrices 
mediated by the interaction of adipose-derived stem cells and endothelial cells, Angiogenesis 17(4) (2014) 921-33.

[107] H. Li, J. Chang, Bioactive silicate materials stimulate angiogenesis in fibroblast and endothelial cell co-culture system through paracrine effect, Acta Biomater. 9(6) (2013) 69816991.

[108] M.N. Nakatsu, R.C. Sainson, J.N. Aoto, K.L. Taylor, M. Aitkenhead, S. Perez-del-Pulgar, P.M. Carpenter, C.C. Hughes, Angiogenic sprouting and capillary lumen formation modeled by human umbilical vein endothelial cells (HUVEC) in fibrin gels: the role of fibroblasts and Angiopoietin-1, Microvasc. Res. 66(2) (2003) 102-12.

[109] N.L. Boyd, S.S. Nunes, L. Krishnan, J.D. Jokinen, V.M. Ramakrishnan, A.R. Bugg, J.B. Hoying, Dissecting the role of human embryonic stem cell-derived mesenchymal cells in human umbilical vein endothelial cell network stabilization in three-dimensional environments, Tissue Eng. Part A 19(1-2) (2013) 211-23.

[110] R.R. Rao, A.W. Peterson, J. Ceccarelli, A.J. Putnam, J.P. Stegemann, Matrix composition regulates three-dimensional network formation by endothelial cells and mesenchymal stem cells in collagen/fibrin materials, Angiogenesis 15(2) (2012) 253-64.

[111] V.M. Delgado, L.G. Nugnes, L.L. Colombo, M.F. Troncoso, M.M. Fernandez, E.L. Malchiodi, I. Frahm, D.O. Croci, D. Compagno, G.A. Rabinovich, C. Wolfenstein-Todel, et al., Modulation of endothelial cell migration and angiogenesis: a novel function for the "tandemrepeat" lectin galectin-8, FASEB J. 25(1) (2011) 242-54.

[112] J. Zhu, W. Cui, X. Liu, J. Ying, C. Hu, Y. Zhang, In vitro and ex vivo angiogenic effects of roxarsone on rat endothelial cells, Toxicol. Lett. 223(2) (2013) 175-82.

[113] S. Kusuma, Y.I. Shen, D. Hanjaya-Putra, P. Mali, L. Cheng, S. Gerecht, Self-organized vascular networks from human pluripotent stem cells in a synthetic matrix, Proc. Natl. Acad. Sci. U. S. A. 110(31) (2013) 12601-6.

[114] R. Sudo, S. Chung, I.K. Zervantonakis, V. Vickerman, Y. Toshimitsu, L.G. Griffith, R.D. Kamm, Transport-mediated angiogenesis in 3D epithelial coculture, FASEB J. 23(7) (2009) 2155-64.

[115] A.A. Ucuzian, D.V. Bufalino, Y. Pang, H.P. Greisler, Angiogenic endothelial cell invasion into fibrin is stimulated by proliferating smooth muscle cells, Microvasc. Res. 90 (2013) 40-7. [116] R. Costa-Almeida, M. Gomez-Lazaro, C. Ramalho, P.L. Granja, R. Soares, S.G. Guerreiro, Fibroblast-endothelial partners for vascularization strategies in tissue engineering, Tissue Eng. Part A 21(5-6) (2015) 1055-65.

[117] A.C. Newman, M.N. Nakatsu, W. Chou, P.D. Gershon, C.C. Hughes, The requirement for fibroblasts in angiogenesis: fibroblast-derived matrix proteins are essential for endothelial cell lumen formation, Mol. Biol. Cell 22(20) (2011) 3791-800.

[118] M.C. Whelan, D.R. Senger, Collagen I initiates endothelial cell morphogenesis by inducing actin polymerization through suppression of cyclic AMP and protein kinase $A, J$. Biol. Chem. 278(1) (2003) 327-34.

[119] J. Sun, N. Jamilpour, F.Y. Wang, P.K. Wong, Geometric control of capillary architecture via cell-matrix mechanical interactions, Biomaterials 35(10) (2014) 3273-80.

[120] L. Knezevic, M. Schaupper, S. Muhleder, K. Schimek, T. Hasenberg, U. Marx, E. Priglinger, H. Redl, W. Holnthoner, Engineering blood and lymphatic microvascular networks in fibrin matrices, Front. Bioeng. Biotechnol. 5 (2017) 25.

[121] Y. Shin, J.S. Jeon, S. Han, G.S. Jung, S. Shin, S.H. Lee, R. Sudo, R.D. Kamm, S. Chung, In vitro 3D collective sprouting angiogenesis under orchestrated ANG-1 and VEGF gradients, Lab Chip 11(13) (2011) 2175-81. 
[122] D. Zhao, C. Xue, S. Lin, S. Shi, Q. Li, M. Liu, X. Cai, Y. Lin, Notch signaling pathway regulates angiogenesis via endothelial cell in 3D co-culture model, J. Cell Physiol. 232(6) (2016) 1548-1558.

[123] R. Auerbach, R. Lewis, B. Shinners, L. Kubai, N. Akhtar, Angiogenesis assays: a critical overview, Clin. Chem. 49(1) (2003) 32-40.

[124] C.E. Fernandez, H.E. Achneck, W.M. Reichert, G.A. Truskey, Biological and engineering design considerations for vascular tissue engineered blood vessels (TEBVs), Curr. Opin. Chem. Eng. 3 (2014) 83-90.

[125] D.P. Sieveking, A. Buckle, D.S. Celermajer, M.K. Ng, Strikingly different angiogenic properties of endothelial progenitor cell subpopulations: insights from a novel human angiogenesis assay, J. Am. Coll. Cardiol. 51(6) (2008) 660-8.

[126] E.A. Stewart, G.J. Samaranayake, A.C. Browning, A. Hopkinson, W.M. Amoaku, Comparison of choroidal and retinal endothelial cells: characteristics and response to VEGF isoforms and anti-VEGF treatments, Exp. Eye Res. 93(5) (2011) 761-6.

[127] C.A. Staton, M.W. Reed, N.J. Brown, A critical analysis of current in vitro and in vivo angiogenesis assays, Int. J. Exp. Pathol. 90(3) (2009) 195-221.

[128] L. Hammoud, J.R. Adams, A.J. Loch, R.C. Marcellus, D.E. Uehling, A. Aman, C. Fladd, T.D. McKee, C.E. Jo, R. Al-Awar, S.E. Egan, et al., Identification of RSK and TTK as modulators of blood vessel morphogenesis using an embryonic stem cell-based vascular differentiation assay, Stem Cell Reports 7(4) (2016) 787-801.

[129] S. Kusuma, S. Gerecht, Recent progress in the use of induced pluripotent stem cells in vascular regeneration, Expert Rev. Cardiovasc. Ther. 11(6) (2013) 661-3.

[130] W. Tancharoen, S. Aungsuchawan, P. Pothacharoen, R. Markmee, S. Narakornsak, J. Kieodee, N. Boonma, W. Tasuya, Differentiation of mesenchymal stem cells from human amniotic fluid to vascular endothelial cells, Acta Histochem. (2016).

[131] K.S. Tan, K. Tamura, M.I. Lai, A. Veerakumarasivam, Y. Nakanishi, M. Ogawa, D. Sugiyama, Molecular pathways governing development of vascular endothelial cells from ES/iPS cells, Stem Cell Rev. 9(5) (2013) 586-98.

[132] A. Noghero, F. Bussolino, A. Gualandris, Role of the microenvironment in the specification of endothelial progenitors derived from embryonic stem cells, Microvasc. Res. 79(3) (2010) 178-83.

[133] H. Kurosawa, Methods for inducing embryoid body formation: in vitro differentiation system of embryonic stem cells, J. Biosci. Bioeng. 103(5) (2007) 389-98.

[134] L. Jakobsson, J. Kreuger, L. Claesson-Welsh, Building blood vessels--stem cell models in vascular biology, J. Cell Biol. 177(5) (2007) 751-5.

[135] A.M. Bratt-Leal, R.L. Carpenedo, T.C. McDevitt, Engineering the embryoid body microenvironment to direct embryonic stem cell differentiation, Biotechnol. Prog. 25(1) (2009) 43-51.

[136] M. Ibrahim, M.K. Richardson, The growth of endothelial-like cells in zebrafish embryoid body culture, (2017) unpublished results.

[137] Y. Wang, D.J. Qian, W.Y. Zhong, J.H. Lu, X.K. Guo, Y.L. Cao, J. Liu, TGF-beta1 induces the formation of vascular-like structures in embryoid bodies derived from human embryonic stem cells, Exp. Ther. Med. 8(1) (2014) 52-58.

[138] D.E. Glaser, A.B. Burns, R. Hatano, M. Medrzycki, Y. Fan, K.E. McCloskey, Specialized mouse embryonic stem cells for studying vascular development, Stem Cells Cloning 7 (2014) 79-88. 
[139] B. Hermant, A. Desroches-Castan, M.L. Dubessay, M.H. Prandini, P. Huber, D. Vittet, Development of a one-step embryonic stem cell-based assay for the screening of sprouting angiogenesis, BMC Biotechnol. 7 (2007) 20.

[140] J. Li, H. Stuhlmann, In vitro imaging of angiogenesis using embryonic stem cell-derived endothelial cells, Stem Cells Dev. 21(2) (2012) 331-42.

[141] L. Jakobsson, C.A. Franco, K. Bentley, R.T. Collins, B. Ponsioen, I.M. Aspalter, I. Rosewell, M. Busse, G. Thurston, A. Medvinsky, S. Schulte-Merker, et al., Endothelial cells dynamically compete for the tip cell position during angiogenic sprouting, Nat. Cell Biol. 12(10) (2010) 943-53.

[142] O. Feraud, M.H. Prandini, D. Vittet, Vasculogenesis and angiogenesis from in vitro differentiation of mouse embryonic stem cells, Methods Enzymol. 365 (2003) 214-28.

[143] N.L. Boyd, S.K. Dhara, R. Rekaya, E.A. Godbey, K. Hasneen, R.R. Rao, F.D. West, 3rd, B.A. Gerwe, S.L. Stice, BMP4 promotes formation of primitive vascular networks in human embryonic stem cell-derived embryoid bodies, Exp. Biol. Med. (Maywood) 232(6) (2007) 833-43.

[144] S. Levenberg, J.S. Golub, M. Amit, J. Itskovitz-Eldor, R. Langer, Endothelial cells derived from human embryonic stem cells, Proc. Natl. Acad. Sci. U. S. A. 99(7) (2002) 4391-6.

[145] R. Fernandez-Alonso, M. Martin-Lopez, L. Gonzalez-Cano, S. Garcia, F. Castrillo, I. DiezPrieto, A. Fernandez-Corona, M.E. Lorenzo-Marcos, X. Li, L. Claesson-Welsh, M.M. Marques, et al., p73 is required for endothelial cell differentiation, migration and the formation of vascular networks regulating VEGF and TGFbeta signaling, Cell Death Differ. 22(8) (2015) 1287-99.

[146] T. Kawamoto, Y. Kobayashi, H. Nakajima, Y. Yamagishi, Generation of robust vascular networks from cardiovascular blast populations derived from human induced pluripotent stem cells in vivo and ex vivo organ culture system, Biochem. Biophys. Res. Commun. 441(1) (2013) 180-5.

[147] P. Zhang, J. Baxter, K. Vinod, T.N. Tulenko, P.J. Di Muzio, Endothelial differentiation of amniotic fluid-derived stem cells: synergism of biochemical and shear force stimuli, Stem Cells Dev. 18(9) (2009) 1299-308.

[148] S. Wang, L. Mundada, S. Johnson, J. Wong, R. Witt, R.G. Ohye, M.S. Si, Characterization and angiogenic potential of human neonatal and infant thymus mesenchymal stromal cells, Stem Cells Transl. Med. 4(4) (2015) 339-50.

[149] S. Koh, J.A. Piedrahita, From "ES-like" cells to induced pluripotent stem cells: a historical perspective in domestic animals, Theriogenology 81(1) (2014) 103-11.

[150] D. Taura, M. Sone, K. Homma, N. Oyamada, K. Takahashi, N. Tamura, S. Yamanaka, K. Nakao, Induction and isolation of vascular cells from human induced pluripotent stem cells-brief report, Arterioscler. Thromb. Vasc. Biol. 29(7) (2009) 1100-3.

[151] R.M. Eman, H.A. Meijer, F.C. Oner, W.J. Dhert, J. Alblas, Establishment of an early vascular network promotes the formation of ectopic bone, Tissue Eng. Part A 22(3-4) (2016) 253-62.

[152] F. Duttenhoefer, R. Lara de Freitas, T. Meury, M. Loibl, L.M. Benneker, R.G. Richards, M. Alini, S. Verrier, 3D scaffolds co-seeded with human endothelial progenitor and mesenchymal stem cells: evidence of prevascularisation within 7 days, Eur. Cell. Mater. 26 (2013) 49-64; discussion 64-5.

[153] G. Keller, Embryonic stem cell differentiation: emergence of a new era in biology and medicine, Genes. Dev. 19(10) (2005) 1129-55. 
[154] S. Yamanaka, Induced pluripotent stem cells: past, present, and future, Cell Stem Cell 10(6) (2012) 678-84.

[155] L. Lin, L. Bolund, Y. Luo, Towards personalized regenerative cell therapy: mesenchymal stem cells derived from human induced pluripotent stem cells, Curr. Stem Cell Res. Ther. 11(2) (2016) 122-30.

[156] S.M. Watt, F. Gullo, M. van der Garde, D. Markeson, R. Camicia, C.P. Khoo, J.J. Zwaginga, The angiogenic properties of mesenchymal stem/stromal cells and their therapeutic potential, Br. Med. Bull. 108 (2013) 25-53.

[157] T. Asahara, T. Murohara, A. Sullivan, M. Silver, R. van der Zee, T. Li, B. Witzenbichler, G. Schatteman, J.M. Isner, Isolation of putative progenitor endothelial cells for angiogenesis, Science 275(5302) (1997) 964-7.

[158] M.C. Yoder, Differentiation of pluripotent stem cells into endothelial cells, Curr. Opin. Hematol. 22(3) (2015) 252-7.

[159] L.B. Bertelsen, A.B. Bohn, M. Smith, B. Molgaard, B. Moller, H. Stodkilde-Jorgensen, P. Kristensen, Are endothelial outgrowth cells a potential source for future re-vascularization therapy?, Exp. Gerontol. 58 (2014) 132-8.

[160] E.A. Kruger, P.H. Duray, D.K. Price, J.M. Pluda, W.D. Figg, Approaches to preclinical screening of antiangiogenic agents, Semin. Oncol. 28(6) (2001) 570-6.

[161] M. Baker, S.D. Robinson, T. Lechertier, P.R. Barber, B. Tavora, G. D'Amico, D.T. Jones, B. Vojnovic, K. Hodivala-Dilke, Use of the mouse aortic ring assay to study angiogenesis, Nat. Protoc. 7(1) (2011) 89-104.

[162] W. Song, C.W. Fhu, K.H. Ang, C.H. Liu, N.A. Johari, D. Lio, S. Abraham, W. Hong, S.E. Moss, J. Greenwood, X. Wang, The fetal mouse metatarsal bone explant as a model of angiogenesis, Nat. Protoc. 10(10) (2015) 1459-73.

[163] S. Rezzola, M. Belleri, G. Gariano, D. Ribatti, C. Costagliola, F. Semeraro, M. Presta, In vitro and ex vivo retina angiogenesis assays, Angiogenesis 17(3) (2014) 429-42.

[164] Z. Shao, M. Friedlander, C.G. Hurst, Z. Cui, D.T. Pei, L.P. Evans, A.M. Juan, H. Tahiri, F. Duhamel, J. Chen, P. Sapieha, et al., Choroid sprouting assay: an ex vivo model of microvascular angiogenesis, PLoS One 8(7) (2013) e69552.

[165] R. Rojas-Rodriguez, O. Gealekman, M.E. Kruse, B. Rosenthal, K. Rao, S. Min, K.D. Bellve, L.M. Lifshitz, S. Corvera, Adipose tissue angiogenesis assay, Methods Enzymol. 537 (2014) 75-91.

[166] R. Auerbach, V. Muthukkaruppan, The chick embryo aortic arch assay, in: E. Zudaire, F. Cuttitta (Eds.), The Textbook of Angiogenesis and Lymphangiogenesis: Methods and Applications, Springer Netherlands, Dordrecht, 2012, pp. 149-157.

[167] C.H. Chen, J. Cartwright, Jr., Z. Li, S. Lou, H.H. Nguyen, A.M. Gotto, Jr., P.D. Henry, Inhibitory effects of hypercholesterolemia and ox-LDL on angiogenesis-like endothelial growth in rabbit aortic explants. Essential role of basic fibroblast growth factor, Arterioscler. Thromb. Vasc. Biol. 17(7) (1997) 1303-12.

[168] J. Stiffey-Wilusz, J.A. Boice, J. Ronan, A.M. Fletcher, M.S. Anderson, An ex vivo angiogenesis assay utilizing commercial porcine carotid artery: modification of the rat aortic ring assay, Angiogenesis 4(1) (2001) 3-9.

[169] G. Alessandri, M. Girelli, G. Taccagni, A. Colombo, R. Nicosia, A. Caruso, M. Baronio, S. Pagano, L. Cova, E. Parati, Human vasculogenesis ex vivo: embryonal aorta as a tool for isolation of endothelial cell progenitors, Lab Invest. 81(6) (2001) 875-85. 
[170] P.J. Williams, J.N. Bulmer, B.A. Innes, F. Broughton Pipkin, Possible roles for folic acid in the regulation of trophoblast invasion and placental development in normal early human pregnancy, Biol. Reprod. 84(6) (2011) 1148-53.

[171] S.P. Jung, B. Siegrist, M.R. Wade, C.T. Anthony, E.A. Woltering, Inhibition of human angiogenesis with heparin and hydrocortisone, Angiogenesis 4(3) (2001) 175-86.

[172] G. Seano, G. Chiaverina, P.A. Gagliardi, L. di Blasio, R. Sessa, F. Bussolino, L. Primo, Modeling human tumor angiogenesis in a three-dimensional culture system, Blood 121(21) (2013) e129-37.

[173] M. Ibrahim, M.K. Richardson, In vitro development of zebrafish vascular networks, Reprod. Toxicol. (2017) DOI: 10.1016/j.reprotox.2017.02.008.

[174] R.F. Nicosia, The aortic ring model of angiogenesis: a quarter century of search and discovery, J. Cell. Mol. Med. 13(10) (2009) 4113-36.

[175] M.W. Irvin, A. Zijlstra, J.P. Wikswo, A. Pozzi, Techniques and assays for the study of angiogenesis, Exp. Biol. Med. (Maywood) 239(11) (2014) 1476-88.

[176] W.H. Zhu, M. Iurlaro, A. MacIntyre, E. Fogel, R.F. Nicosia, The mouse aorta model: influence of genetic background and aging on bFGF- and VEGF-induced angiogenic sprouting, Angiogenesis 6(3) (2003) 193-9.

[177] R.F. Nicosia, W.H. Zhu, E. Fogel, K.M. Howson, A.C. Aplin, A new ex vivo model to study venous angiogenesis and arterio-venous anastomosis formation, J. Vasc. Res. 42(2) (2005) 111-9.

[178] M.J. Reed, N. Karres, D. Eyman, R.B. Vernon, Culture of murine aortic explants in 3dimensional extracellular matrix: a novel, miniaturized assay of angiogenesis in vitro, Microvasc. Res. 73(3) (2007) 248-52.

[179] Q. Li, B.R. Olsen, Increased angiogenic response in aortic explants of collagen XVIII/endostatin-null mice, Am. J. Pathol. 165(2) (2004) 415-24.

[180] N.A. Mikirova, J.J. Casciari, N.H. Riordan, Ascorbate inhibition of angiogenesis in aortic rings ex vivo and subcutaneous Matrigel plugs in vivo, J. Angiogenes Res. 2 (2010) 2.

[181] T. Kiziltepe, K.C. Anderson, J.L. Kutok, L. Jia, K.M. Boucher, J.E. Saavedra, L.K. Keefer, P.J. Shami, JS-K has potent anti-angiogenic activity in vitro and inhibits tumour angiogenesis in a multiple myeloma model in vivo, J. Pharm. Pharmacol. 62(1) (2010) 145-51.

[182] M.J. Reed, M. Damodarasamy, R.B. Vernon, Angiogenesis in vitro utilizing murine vascular explants in miniaturized 3-dimensional collagen gels, Open Circ. Vasc. J. 4 (2011) 1217.

[183] S. Sawamiphak, M. Ritter, A. Acker-Palmer, Preparation of retinal explant cultures to study ex vivo tip endothelial cell responses, Nat. Protoc. 5(10) (2010) 1659-65.

[184] S. Rezzola, M. Belleri, D. Ribatti, C. Costagliola, M. Presta, F. Semeraro, A novel ex vivo murine retina angiogenesis (EMRA) assay, Exp. Eye. Res. 112 (2013) 51-6.

[185] Z. Liu, F. Lebrin, J.A. Maring, S. van den Driesche, S. van der Brink, M. van Dinther, M. Thorikay, S. Martin, K. Kobayashi, L.J. Hawinkels, L.A. van Meeteren, et al., ENDOGLIN is dispensable for vasculogenesis, but required for vascular endothelial growth factor-induced angiogenesis, PLoS One 9(1) (2014) e86273.

[186] J. Niderla-Bielinska, B. Ciszek, E. Jankowska-Steifer, A. Flaht-Zabost, G. Gula, D.M. Radomska-Lesniewska, A. Ratajska, Mouse proepicardium exhibits a sprouting response to exogenous proangiogenic growth factors in vitro, J. Vasc. Res. 53(1-2) (2016) 83-93.

[187] R. Spence, G. Gerlach, C. Lawrence, C. Smith, The behaviour and ecology of the zebrafish, Danio rerio, Biol. Rev. Camb. Philos. Soc. 83(1) (2008) 13-34. 
[188] S. Hasso, J. Chan, Chemical approaches to angiogenesis in development and regeneration, Methods Cell Biol. 101 (2011) 181-95.

[189] S. Ali, D.L. Champagne, H.P. Spaink, M.K. Richardson, Zebrafish embryos and larvae: a new generation of disease models and drug screens, Birth Defects Res. C Embryo Today 93(2) (2011) 115-33.

[190] A. Schuermann, C.S. Helker, W. Herzog, Angiogenesis in zebrafish, Semin. Cell Dev. Biol. 31 (2014) 106-14.

[191] E. Ellertsdottir, A. Lenard, Y. Blum, A. Krudewig, L. Herwig, M. Affolter, H.G. Belting, Vascular morphogenesis in the zebrafish embryo, Dev. Biol. 341(1) (2010) 56-65.

[192] F. Wu, H. Song, Y. Zhang, Y. Zhang, Q. Mu, M. Jiang, F. Wang, W. Zhang, L. Li, H. Li, Y. Wang, et al., Irisin induces angiogenesis in human umbilical vein endothelial cells in Vitro and in zebrafish embryos in vivo via activation of the ERK signaling pathway, PLoS One 10(8) (2015) e0134662.

[193] R.T. Peterson, S.Y. Shaw, T.A. Peterson, D.J. Milan, T.P. Zhong, S.L. Schreiber, C.A. MacRae, M.C. Fishman, Chemical suppression of a genetic mutation in a zebrafish model of aortic coarctation, Nat. Biotechnol. 22(5) (2004) 595-9.

[194] M. Konantz, T.B. Balci, U.F. Hartwig, G. Dellaire, M.C. Andre, J.N. Berman, C. Lengerke, Zebrafish xenografts as a tool for in vivo studies on human cancer, Ann. N. Y. Acad. Sci. 1266 (2012) 124-37.

[195] M. Haldi, C. Ton, W.L. Seng, P. McGrath, Human melanoma cells transplanted into zebrafish proliferate, migrate, produce melanin, form masses and stimulate angiogenesis in zebrafish, Angiogenesis 9(3) (2006) 139-51.

[196] S. Nicoli, M. Presta, The zebrafish/tumor xenograft angiogenesis assay, Nat. Protoc. 2(11) (2007) 2918-23.

[197] L. Mercatali, F. La Manna, A. Groenewoud, R. Casadei, F. Recine, G. Miserocchi, F. Pieri, C. Liverani, A. Bongiovanni, C. Spadazzi, A. de Vita, et al., Development of a patient-derived xenograft (PDX) of breast cancer bone metastasis in a zebrafish model, Int. J. Mol. Sci. 17(8) (2016).

[198] W. van der Ent, C. Burrello, M.J. de Lange, P.A. van der Velden, A.G. Jochemsen, M.J. Jager, B.E. Snaar-Jagalska, Embryonic zebrafish: different phenotypes after injection of human uveal melanoma Cells, Ocul. Oncol. Pathol. 1(3) (2015) 170-81.

[199] X. Chen, J. Wang, Z. Cao, K. Hosaka, L. Jensen, H. Yang, Y. Sun, R. Zhuang, Y. Liu, Y. Cao, Invasiveness and metastasis of retinoblastoma in an orthotopic zebrafish tumor model, Sci. Rep. 5 (2015) 10351.

[200] K.D. Poss, M.T. Keating, A. Nechiporuk, Tales of regeneration in zebrafish, Dev. Dyn. 226(2) (2003) 202-10.

[201] K.D. Poss, L.G. Wilson, M.T. Keating, Heart regeneration in zebrafish, Science 298(5601) (2002) 2188-90.

[202] W. Shi, Z. Fang, L. Li, L. Luo, Using zebrafish as the model organism to understand organ regeneration, Sci. China Life Sci. 58(4) (2015) 343-51.

[203] X.Y. Zhang, A.R. Rodaway, SCL-GFP transgenic zebrafish: in vivo imaging of blood and endothelial development and identification of the initial site of definitive hematopoiesis, Dev. Biol. 307(2) (2007) 179-94.

[204] S.W. Jin, D. Beis, T. Mitchell, J.N. Chen, D.Y. Stainier, Cellular and molecular analyses of vascular tube and lumen formation in zebrafish, Development 132(23) (2005) 5199-209.

[205] T. Tal, C. Kilty, A. Smith, C. LaLone, B. Kennedy, A. Tennant, C.W. McCollum, M. Bondesson, T. Knudsen, S. Padilla, N. Kleinstreuer, Screening for angiogenic inhibitors in 
zebrafish to evaluate a predictive model for developmental vascular toxicity, Reprod. Toxicol. (2016) http://dx.doi.org/10.1016/j.reprotox.2016.12.004.

[206] T. Motoike, S. Loughna, E. Perens, B.L. Roman, W. Liao, T.C. Chau, C.D. Richardson, T. Kawate, J. Kuno, B.M. Weinstein, D.Y. Stainier, et al., Universal GFP reporter for the study of vascular development, Genesis 28(2) (2000) 75-81.

[207] Z. Liu, F. Liu, Cautious use of fli1a:EGFP transgenic zebrafish in vascular research, Biochem. Biophys. Res. Commun. 427(1) (2012) 223-6.

[208] C.A. Ciarlo, L.I. Zon, Chapter 1 - Embryonic cell culture in zebrafish, in: M.W. H. William Detrich, I.Z. Leonard (Eds.), Methods in Cell Biology, Academic Press2016, pp. 1-10.

[209] S. Choorapoikayil, J. Overvoorde, J. den Hertog, Deriving cell lines from zebrafish embryos and tumors, Zebrafish 10(3) (2013) 316-25.

[210] K. Henn, Limits of fish embryo toxicity test with Danio rerio as an alternative to the acute fish toxicity test, Center of Organismal Studies Heidelberg (COS), Ruperto-Carola University, Heidelberg, Germany, 2011, p. 91.

[211] L. Fan, P. Collodi, Zebrafish embryonic stem cells, Methods Enzymol. 418 (2006) 64-77.

[212] N. Hong, M. Schartl, Y. Hong, Derivation of stable zebrafish ES-like cells in feeder-free culture, Cell Tissue Res. 357(3) (2014) 623-32.

[213] M.C. Alvarez, J. Bejar, S. Chen, Y. Hong, Fish ES cells and applications to biotechnology, Mar. Biotechnol. (NY) 9(2) (2007) 117-27.

[214] N. Hong, Z. Li, Y. Hong, Fish stem cell cultures, Int. J. Biol. Sci. 7(4) (2011) 392-402.

[215] J.G. Xing, L.E.J. Lee, L.C. Fan, P. Collodi, S.E. Holt, N.C. Bols, Initiation of a zebrafish blastula cell line on rainbow trout stromal cells and subsequent development under feederfree conditions into a cell line, ZEB2J, Zebrafish 5(1) (2008) 49-63.

[216] J.L. Myhre, D.B. Pilgrim, Cellular differentiation in primary cell cultures from single zebrafish embryos as a model for the study of myogenesis, Zebrafish 7(3) (2010) 255-66.

[217] C. Xu, M. Tabebordbar, S. Iovino, C. Ciarlo, J. Liu, A. Castiglioni, E. Price, M. Liu, Elisabeth R. Barton, C.R. Kahn, Amy J. Wagers, et al., A zebrafish embryo culture system defines factors that promote vertebrate myogenesis across species, Cell 155(4) (2013) 909921.

[218] W. Norris, C. Neyt, P.W. Ingham, P.D. Currie, Slow muscle induction by Hedgehog signalling in vitro, J. Cell Sci. 113 ( Pt 15) (2000) 2695-703.

[219] Y. Xiao, M. Gao, L. Gao, Y. Zhao, Q. Hong, Z. Li, J. Yao, H. Cheng, R. Zhou, Directed differentiation of zebrafish pluripotent embryonic cells to functional cardiomyocytes, Stem Cell Reports 7(3) (2016) 370-82.

[220] M.F. Riesco, D.G. Valcarce, J. Alfonso, M.P. Herraez, V. Robles, In vitro generation of zebrafish PGC-like cells, Biol. Reprod. 91(5) (2014) 114.

[221] H.G. Huang, A. Lindgren, X.R. Wu, N.A. Liu, S.O. Lin, High-throughput screening for bioactive molecules using primary cell culture of transgenic zebrafish embryos, Cell Rep. 2(3) (2012) 695-704.

[222] B. Kinikoglu, Y. Kong, E.C. Liao, Characterization of cultured multipotent zebrafish neural crest cells, Exp. Biol. Med. (Maywood) 239(2) (2014) 159-68.

[223] Z. Chen, H. Lee, S.J. Henle, T.R. Cheever, S.C. Ekker, J.R. Henley, Primary neuron culture for nerve growth and axon guidance studies in zebrafish (Danio rerio), PLoS One 8(3) (2013) e57539.

[224] A. Fatehullah, S.H. Tan, N. Barker, Organoids as an in vitro model of human development and disease, Nat. Cell Biol. 18(3) (2016) 246-254. 
[225] M.A. Lancaster, J.A. Knoblich, Organogenesis in a dish: Modeling development and disease using organoid technologies, Science 345(6194) (2014).

[226] S. Bartfeld, H. Clevers, Stem cell-derived organoids and their application for medical research and patient treatment, J. Mol. Med. (Berl) (2017).

[227] M.A. Lancaster, J.A. Knoblich, Generation of cerebral organoids from human pluripotent stem cells, Nat. Protoc. 9(10) (2014) 2329-2340.

[228] I. Kelava, M.A. Lancaster, Stem Cell Models of Human Brain Development, Cell Stem Cell 18(6) (2016) 736-48.

[229] S.B. Shah, A. Singh, Cellular self-assembly and biomaterials-based organoid models of development and diseases, Acta Biomater. 53 (2017) 29-45.

[230] M.P. Schwartz, Z. Hou, N.E. Propson, J. Zhang, C.J. Engstrom, V. Santos Costa, P. Jiang, B.K. Nguyen, J.M. Bolin, W. Daly, Y. Wang, et al., Human pluripotent stem cell-derived neural constructs for predicting neural toxicity, Proc. Natl. Acad. Sci. U. S. A. 112(40) (2015) 1251621.

[231] M.E. Boutin, L.L. Kramer, L.L. Livi, T. Brown, C. Moore, D. Hoffman-Kim, A threedimensional neural spheroid model for capillary-like network formation, J. Neurosci. Methods (2017).

[232] C.L. Watson, M.M. Mahe, J. Munera, J.C. Howell, N. Sundaram, H.M. Poling, J.I. Schweitzer, J.E. Vallance, C.N. Mayhew, Y. Sun, G. Grabowski, et al., An in vivo model of human small intestine using pluripotent stem cells, Nat. Med. 20(11) (2014) 1310-4.

[233] A.A. Khan, S.K. Vishwakarma, A. Bardia, J. Venkateshwarulu, Repopulation of decellularized whole organ scaffold using stem cells: an emerging technology for the development of neo-organ, J. Artif. Organs 17(4) (2014) 291-300.

[234] H.C. Ott, T.S. Matthiesen, S.K. Goh, L.D. Black, S.M. Kren, T.I. Netoff, D.A. Taylor, Perfusion-decellularized matrix: using nature's platform to engineer a bioartificial heart, Nat. Med. 14(2) (2008) 213-21.

[235] L. Dew, W.R. English, C.K. Chong, S. MacNeil, Investigating neovascularization in rat decellularized intestine: an in vitro platform for studying angiogenesis, Tissue Eng. Part $A$ 22(23-24) (2016) 1317-1326.

[236] S. Bersini, I.K. Yazdi, G. Talo, S.R. Shin, M. Moretti, A. Khademhosseini, Cellmicroenvironment interactions and architectures in microvascular systems, Biotechnol. Adv. 34(6) (2016) 1113-30.

[237] S. Kim, H. Lee, M. Chung, N.L. Jeon, Engineering of functional, perfusable 3D microvascular networks on a chip, Lab Chip 13(8) (2013) 1489-500.

[238] S. Kim, M. Chung, J. Ahn, S. Lee, N.L. Jeon, Interstitial flow regulates the angiogenic response and phenotype of endothelial cells in a 3D culture model, Lab Chip 16(21) (2016) 4189-4199.

[239] D.H. Nguyen, S.C. Stapleton, M.T. Yang, S.S. Cha, C.K. Choi, P.A. Galie, C.S. Chen, Biomimetic model to reconstitute angiogenic sprouting morphogenesis in vitro, Proc. Natl. Acad. Sci. U. S. A. 110(17) (2013) 6712-7.

[240] J.S. Jeon, S. Bersini, M. Gilardi, G. Dubini, J.L. Charest, M. Moretti, R.D. Kamm, Human $3 \mathrm{D}$ vascularized organotypic microfluidic assays to study breast cancer cell extravasation, Proc. Natl. Acad. Sci. U. S. A. 112(1) (2015) 214-9.

[241] M.B. Chen, J.A. Whisler, J. Frose, C. Yu, Y. Shin, R.D. Kamm, On-chip human microvasculature assay for visualization and quantification of tumor cell extravasation dynamics, Nat. Protoc. 12(5) (2017) 865-880. 
[242] L.B. Wood, R. Ge, R.D. Kamm, H.H. Asada, Nascent vessel elongation rate is inversely related to diameter in in vitro angiogenesis, Integr. Biol. (Camb.) 4(9) (2012) 1081-9.

[243] A. Sobrino, D.T. Phan, R. Datta, X. Wang, S.J. Hachey, M. Romero-Lopez, E. Gratton, A.P. Lee, S.C. George, C.C. Hughes, 3D microtumors in vitro supported by perfused vascular networks, Sci. Rep. 6 (2016) 31589.

[244] D.G. Belair, J.A. Whisler, J. Valdez, J. Velazquez, J.A. Molenda, V. Vickerman, R. Lewis, C. Daigh, T.D. Hansen, D.A. Mann, J.A. Thomson, et al., Human vascular tissue models formed from human induced pluripotent stem cell derived endothelial cells, Stem Cell Rev. 11(3) (2015) 511-25.

[245] M.R. Zanotelli, H. Ardalani, J. Zhang, Z. Hou, E.H. Nguyen, S. Swanson, B.K. Nguyen, J. Bolin, A. Elwell, L.L. Bischel, A.W. Xie, et al., Stable engineered vascular networks from human induced pluripotent stem cell-derived endothelial cells cultured in synthetic hydrogels, Acta Biomater. 35 (2016) 32-41.

[246] M.L. Moya, Y.H. Hsu, A.P. Lee, C.C. Hughes, S.C. George, In vitro perfused human capillary networks, Tissue Eng. Part C Methods 19(9) (2013) 730-7.

[247] L.F. Alonzo, M.L. Moya, V.S. Shirure, S.C. George, Microfluidic device to control interstitial flow-mediated homotypic and heterotypic cellular communication, Lab Chip 15(17) (2015) 3521-9.

[248] Y. Zheng, J. Chen, M. Craven, N.W. Choi, S. Totorica, A. Diaz-Santana, P. Kermani, B. Hempstead, C. Fischbach-Teschl, J.A. Lopez, A.D. Stroock, In vitro microvessels for the study of angiogenesis and thrombosis, Proc. Natl. Acad. Sci. U. S. A. 109(24) (2012) 9342-7.

[249] B. Zhang, M. Montgomery, M.D. Chamberlain, S. Ogawa, A. Korolj, A. Pahnke, L.A. Wells, S. Masse, J. Kim, L. Reis, A. Momen, et al., Biodegradable scaffold with built-in vasculature for organ-on-a-chip engineering and direct surgical anastomosis, Nat. Mater. 15(6) (2016) 669-78.

[250] D. Huh, B.D. Matthews, A. Mammoto, M. Montoya-Zavala, H.Y. Hsin, D.E. Ingber, Reconstituting organ-level lung functions on a chip, Science 328(5986) (2010) 1662-8.

[251] A.K. Achyuta, A.J. Conway, R.B. Crouse, E.C. Bannister, R.N. Lee, C.P. Katnik, A.A. Behensky, J. Cuevas, S.S. Sundaram, A modular approach to create a neurovascular unit-ona-chip, Lab Chip 13(4) (2013) 542-53.

[252] J.A. Brown, S.G. Codreanu, M. Shi, S.D. Sherrod, D.A. Markov, M.D. Neely, C.M. Britt, O.S. Hoilett, R.S. Reiserer, P.C. Samson, L.J. McCawley, et al., Metabolic consequences of inflammatory disruption of the blood-brain barrier in an organ-on-chip model of the human neurovascular unit, J. Neuroinflammation 13(1) (2016) 306.

[253] Y.H. Hsu, M.L. Moya, C.C. Hughes, S.C. George, A.P. Lee, A microfluidic platform for generating large-scale nearly identical human microphysiological vascularized tissue arrays, Lab Chip 13(15) (2013) 2990-8.

[254] Y.H. Hsu, M.L. Moya, P. Abiri, C.C. Hughes, S.C. George, A.P. Lee, Full range physiological mass transport control in 3D tissue cultures, Lab Chip 13(1) (2013) 81-9.

[255] D. Huh, H.J. Kim, J.P. Fraser, D.E. Shea, M. Khan, A. Bahinski, G.A. Hamilton, D.E. Ingber, Microfabrication of human organs-on-chips, Nat. Protoc. 8(11) (2013) 2135-57.

[256] S.N. Bhatia, D.E. Ingber, Microfluidic organs-on-chips, Nat. Biotechnol. 32(8) (2014) 760-72. 